University of Nebraska - Lincoln

DigitalCommons@University of Nebraska - Lincoln

\title{
Tracking solutes and water from subsurface drip irrigation application of coalbed methane-produced waters, Powder River Basin, Wyoming
}

\author{
Mark A. Engle \\ U.S. Geological Survey, Reston, Virginia, engle@usgs.gov \\ Carleton R. Bern \\ U.S. Geological Survey, Denver, Colorado, cbern@usgs.gov \\ Richard W. Healy \\ U.S. Geological Survey, rwhealy@usgs.gov \\ James I. Sams \\ U.S. Dept. of Energy, james.sams@netl.doe.gov \\ John W. Zupancic \\ BeneTerra, LLC, johnz@beneterra.com \\ See next page for additional authors \\ Follow this and additional works at: https://digitalcommons.unl.edu/usgsstaffpub \\ Part of the Earth Sciences Commons
}

Engle, Mark A.; Bern, Carleton R.; Healy, Richard W.; Sams, James I.; Zupancic, John W.; and Schroeder, Karl T., "Tracking solutes and water from subsurface drip irrigation application of coalbed methane-produced waters, Powder River Basin, Wyoming" (2011). USGS Staff -- Published Research. 508.

https://digitalcommons.unl.edu/usgsstaffpub/508

This Article is brought to you for free and open access by the US Geological Survey at DigitalCommons@University of Nebraska - Lincoln. It has been accepted for inclusion in USGS Staff -- Published Research by an authorized administrator of DigitalCommons@University of Nebraska - Lincoln. 


\section{Authors}

Mark A. Engle, Carleton R. Bern, Richard W. Healy, James I. Sams, John W. Zupancic, and Karl T. Schroeder 


\section{Tracking solutes and water from subsurface drip irrigation application of coalbed methane-produced waters, Powder River Basin, Wyoming}

\author{
Mark A. Engle, Carleton R. Bern, Richard W. Healy, \\ James I. Sams, John W. Zupancic, and Karl T. Schroeder
}

\begin{abstract}
One method to beneficially use water produced from coalbed methane (CBM) extraction is subsurface drip irrigation (SDI) of croplands. In SDI systems, treated CBM water (injectate) is supplied to the soil at depth, with the purpose of preventing the buildup of detrimental salts near the surface. The technology is expanding within the Powder River Basin, but little research has been published on its environmental impacts. This article reports on initial results from tracking water and solutes from the injected CBM-produced waters at an SDI system in Johnson County, Wyoming.

In the first year of SDI operation, soil moisture significantly increased in the SDI areas, but well water levels increased only modestly, suggesting that most of the water added was stored in the vadose zone or lost to evapotranspiration. The injectate has lower concentrations of most inorganic constituents relative to ambient groundwater at the site but exhibits a high sodium adsorption ratio. Changes in groundwater chemistry during the same period of SDI operation were small; the increase in groundwater-specific conductance relative to pre-SDI conditions was observed in a single well. Conversely, groundwater samples collected beneath another SDI field showed decreased concentrations of several constituents since the SDI operation. Groundwater-specific conductance at the 12 other wells showed no significant changes. Major controls on and compositional variability of groundwater, surface water, and soil water chemistry are discussed in detail. Findings from this research provide an understanding of water and salt dynamics associated with SDI systems using CBM-produced water.
\end{abstract}

This article is a U.S. government work, and is not subject to copyright in the United States.

Copyright (C2011. The American Association of Petroleum Geologists/Division of Environmental Geosciences. All rights reserved.

DOI:10.1306/eg.03031111004

\section{AUTHORS}

Mark A. ENGLE U.S. Geological Survey, Reston, Virginia; engle@usgs.gov

Mark A. Engle is a research geologist at the U.S. Geological Survey in Reston, Virginia. He currently serves as chief of the produced waters project for the U.S. Geological Survey Energy Resources Program. He holds a Ph.D. in hydrogeology from the University of Nevada, Reno. His research interests include aqueous geochemistry and geochemometrics.

CARLETON R. BERN U.S. Geological Survey, Denver, Colorado; cbern@usgs.gov

Carleton R. Bern is a research soil scientist at the U.S. Geological Survey in Denver, Colorado. He received his Ph.D. in ecology and evolutionary biology from the University of Colorado. His research interests include soil isotopic geochemistry and geochemical modeling of soil processes.

Richard W. Healy U.S. Geological Survey, Denver, Colorado; rwhealy@usgs.gov

Richard W. Healy is a research hydrologist at the U.S. Geological Survey in Lakewood, Colorado. His research interests include estimating groundwater recharge and flow and solute transport within the unsaturated zone. He received his B.S. and M.S. degrees in mathematics from the University of Illinois.

JAMES I. SAMS $\sim$ National Energy Technology Laboratory, U.S. Dept. of Energy, Pittsburgh, Pennsylvania; james.sams@netl.doe.gov

James I. Sams is a hydrologist and a geographic information system analyst for the Geosciences Division, National Energy Technology Laboratory, U.S. Department of Energy, Pittsburgh, Pennsylvania. He received his master's degree in environmental science from the Pennsylvania State University. His research interests include near-surface geophysics and geospatial analysis.

JOHN W. ZUPANCIC $\sim$ BeneTerra, LLC, Sheridan,Wyoming; johnz@beneterra.com

John W. Zupancic is a founding partner of BeneTerra, LLC, and serves as chief technical officer. As a soil scientist with an interest in water and the environment, he has worked to find beneficial uses for wastewater throughout his career. 
KARL T. SCHROEDER National Energy Technology Laboratory, U.S. Dept. of Energy, Pittsburgh, Pennsylvania; karl.schroeder@netl.doe.gov

Karl T. Schroeder earned a B.S. degree in chemistry from the University of Dayton and a Ph.D. in organic chemistry from Duquesne University. He has been employed as a research chemist at the U.S. Department of Energy for 35 yr. His early work concentrated on direct coal liquefaction technology but has shifted to environmental problems associated with fossil fuel production and use.

\section{ACKNOWLEDGEMENTS}

Funding for this project was provided by the U.S. Department of Energy (DOE) and U.S. Geological Survey Energy Resources Program. The authors thank Don Fischer and Ursula Williams from the Wyoming Department of Environmental Quality for providing technical support and assistance. Garret Veloski (DOE), Rick Hammack (DOE), Bruce Smith (U.S. Geological Survey), and Burke Minsley (U.S. Geological Survey) provided significant project guidance and shared interpretation of the geophysical results. Jim Otton (U.S. Geological Survey) and Cyndi Rice (U.S. Geological Survey) provided initial project management and expertise on CBM-produced waters. George Breit (U.S. Geological Survey), Kevin Jones (U.S. Geological Survey), and four anonymous reviewers provided constructive comments on a preliminary version of this article. Assistance with sampling logistics and analytical results were provided by Carol Cardone (National Energy Technology Laboratory [NETL]), Robert Thompson (NETL), and Kristen Carlisle (NETL). Adam Quist (BeneTerra), Bruce Engle (U.S. Geological Survey Volunteer), James Cannia and the rest of the U.S. Geological Survey Nebraska drilling crew greatly assisted with fieldwork.

\section{INTRODUCTION}

Coalbed methane (CBM) is a source of natural gas that is recovered by dewatering coal beds and collecting volatile compounds, such as methane, that are desorbed from the coal. Coalbed methane currently accounts for approximately $7 \%$ of U.S. natural-gas production (U.S. Energy Information Administration, 2009) but, in general, results in extraction of much more water per volume of gas than traditional natural-gas production (Rice and Nuccio, 2000). The Powder River Basin (PRB) of Wyoming and Montana is the second largest producer of $\mathrm{CBM}$ in the United States and generates roughly $1.58 \times$ $10^{10} \mathrm{~m}^{3}$ (560 bcf) of natural gas and more than $9.0 \times 10^{7} \mathrm{~m}^{3}(2.4 \times$ $10^{10} \mathrm{gal}$ ) of produced water per year, based on 2009 data (Wyoming Oil and Gas Conservation Commission, 2010). At present, very little of this CBM-produced water is disposed of by subsurface injection.

The release of CBM-produced waters onto the ground surface and into drainages of the PRB is of concern, given their high sodium adsorption ratio ([SAR] range, 5.6-69) and locally moderate total dissolved solids (TDS) concentration (range, 200-4000 mg/L) (Bartos and Ogle, 2002; Rice et al., 2002; Jackson and Reddy, 2007). The $\mathrm{SAR}$ is an empirical metric to estimate the relative ability of $\mathrm{Na}$ to replace $\mathrm{Ca}$ and $\mathrm{Mg}$ in soils:

$$
S A R=\frac{\left[\mathrm{Na}^{+}\right]}{\sqrt{0.5\left(\left[\mathrm{Ca}^{2+}\right]+\left[\mathrm{Mg}^{2+}\right]\right)}}
$$

The increase in the relative proportion of $\mathrm{Na}$ can cause dispersion of soil colloids and ultimately degrade soil structure and permeability (Gupta et al., 1984).

Potential damage to soil and stream ecosystems has prompted the development of several innovative technologies to dispose of or beneficially use CBM-produced waters in a manner that minimizes environmental damage. Currently, most of the CBM-produced water from the PRB is placed in infiltration impoundments, as suggested in the Federal Environmental Impact Statement for PRB oil and gas projects in Wyoming (U.S. Bureau of Land Management, 2003). However, impacts to water quality and the presence of readily soluble naturally occurring salts in the vadose zone have raised concerns about infiltration disposal methods (Healy et al., 2008; Lipinski et al., 2008). In addition, Wyoming has mandated that all state water rights be predicated on the beneficial use of that water, such as irrigation for agricultural use (Wyoming Statute 41-3-101). Previous studies have investigated the potential impacts from direct application of CBMproduced waters to the surface agricultural fields (Ganjegunte et al., 2005, 2008; Brinck and Frost, 2009). Despite additional amendment of the soils with gypsum, a source of $\mathrm{Ca}$ and $\mathrm{SO}_{4}$, most of the fields irrigated with CBM-produced water showed dramatic increases in SAR and soil salinity in the upper $60 \mathrm{~cm}$ (24 in.) of the soil column relative to nonirrigated fields (Ganjegunte et al., 2005, 2008). Therefore, additional methods to beneficially use CBM-produced waters 
from the PRB, which minimize negative environmental impacts, are being identified.

Subsurface drip irrigation (SDI) is an emerging technology for the beneficial use of CBM waters in the PRB. Effectively, SDI consists of a method to distribute the CBM water through a system of buried pipes and then disperse it into the root zone of agricultural fields to aid irrigation. Subsurface drip irrigation fundamentally differs from surface irrigation by applying water directly to the root zone to produce forage crops, such as alfalfa, thus minimizing water loss through evaporation and limiting the transfer of solutes in the irrigation water to the Na-sensitive upper soil horizons. This technology has worked successfully in desert environments and in agricultural fields with shallow water tables (Ayars et al., 2001). The beneficial use of CBMproduced waters via SDI is a recent development, but SDI can be theoretically used with most $\mathrm{Na}-\mathrm{HCO}_{3}-$ type waters for the irrigation of a variety of perennial plants, including forage crops and fruit or nut trees, depending on climate, at sites with permeability adequate enough to handle the application rates. Unlike surface application of CBM waters, little information exists to address potential environmental impacts from SDI application of CBM waters.

This article presents the changes to soil moisture and water quality after the first 1 year of SDI application of CBM at the Headgate Draw site, Johnson County, Wyoming (Figure 1). This research is one part of a larger 5 -yr project to (1) assess short- and long-term effects on soil and water quality from SDI operation within the PRB and to (2) identify operational issues that can be used to improve SDI operations for future sites and applications.

\section{SITE DESCRIPTION AND SUBSURFACE DRIP IRRIGATION INSTALLATION}

The Headgate Draw SDI site is adjacent to the Powder River, near its confluence with a major tributary, Crazy Woman Creek, in Johnson County, Wyoming (Figure 1). The regional climate is semiarid (mean annual precipitation, $34.5 \mathrm{~cm}$ [13.6 in.]) and features cold winters with average daily temperatures below freezing, short hot summers, and maximum average monthly precipitation in May and June (Western Regional Climate Center, 2010). Wet, warmer periods in the spring provide most of the precipitation and historically supported nonirrigated agriculture on parts of the Headgate Draw site. However, the overall arid environment of the PRB allows for evapotranspiration rates to exceed precipitation, leading to the formation of salts, such as gypsum, calcite, and thenardite, in the shallow subsurface (Brinck et al., 2008; Healy et al., 2008).

The Headgate Draw site crosses three river terraces above a Quaternary unconfined alluvial aquifer system paralleling the Powder River (Figure 1). These terraces overlie the Paleocene Fort Union and the Eocene Wasatch formations, both of which contain coal beds that are targets for CBM development. The geology and age of the terraces and underlying units are described in detail by Leopold and Miller (1954). The SDI fields are primarily located on the intermediate-age Moorcroft terrace, except for the field north and west of monitoring well (MW) 09MW, which is located on the Kaycee terrace, the highest and oldest terrace (Figure 1). At the Headgate Draw site, the surfaces of these terraces

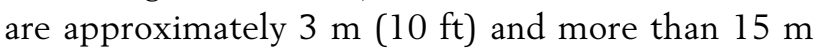
$(>50 \mathrm{ft}$ ), respectively, above the Powder River and the water table. Both terraces are primarily composed of Kaycee Formation sediments, although some older units are present beneath the Kaycee terrace. The Kaycee Formation consists of recent moderately well-sorted silt and fine sand, with lenses of sand and gravel. Organicrich layers and zones of coal and/or charcoal mixed in with the fine sand are also present throughout parts of the site. Some cores collected at the base of the Kaycee Formation intersect a massive clay unit more than 6 to $7.5 \mathrm{~m}(>20-25 \mathrm{ft}$ ) below the top of the Moorcroft terrace. The clay is considered an aquitard and a lower bounding layer of the alluvial aquifer. A small part of the site adjacent to the Powder River, such as areas near wells $06 \mathrm{MW}$ and $11 \mathrm{MW}$, lies on the slightly lower fill terrace known as the Lightning terrace. This lowest terrace is composed of light brown to tan-colored silt and fine sand of the Lightning Formation, with a surface approximately $1.5 \mathrm{~m}(\sim 5 \mathrm{ft})$ above the water table and the elevation of the Powder River.

The SDI system was installed at the Headgate Draw site during the summer and fall of 2008 and began operation in October 2008. Only parts of the site with good drainage and low salt content, as determined by results from geophysical surveys (Sams et al., 2010) and soil sampling, were augmented with SDI (Figure 1). The remainder of the site, referred to as the non-SDI area in this article, is a combination of uncultivated rangeland and nonirrigated agricultural fields. As part of the SDI system, parallel high-density polyethylene (HDPE) laterals were installed $1.4 \mathrm{~m}(4 \mathrm{ft})$ apart at a 


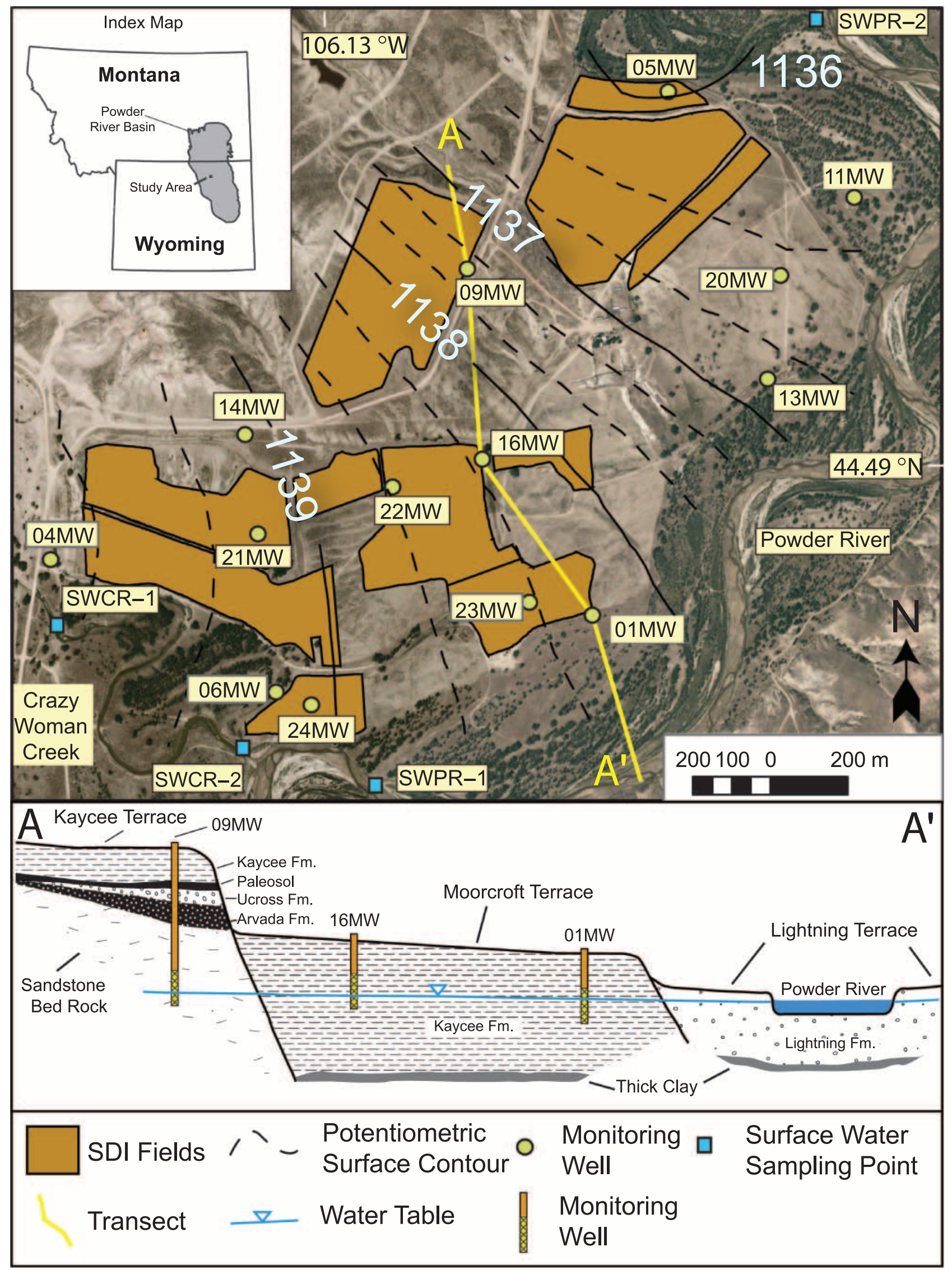


depth of approximately $0.9 \mathrm{~m}(\sim 3 \mathrm{ft})$. Water is introduced to the root zone by one-way emitters located

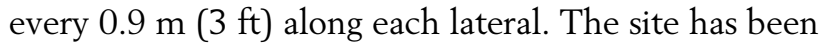
permitted by the state of Wyoming to accept between

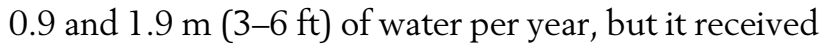
an average of only $0.36 \mathrm{~m}(1.2 \mathrm{ft})$ during the first year of operation because of a slowdown in gas and water production in the PRB.

The raw CBM water is routed from nearby wells into a lined settling pond on the site. Although the wells routed into the system change over time, the water comes from only few coal seams in the Fort Union Formation distributed over a relatively small area. Water from the pond is piped into a pump house where it is filtered, acidified with $\mathrm{H}_{2} \mathrm{SO}_{4}$ to a $\mathrm{pH}$ of approximately 5 , and chlorinated. This "treated" CBM water, known as injectate, is then distributed via the SDI system. The purpose of $\mathrm{H}_{2} \mathrm{SO}_{4}$ acidification is to reduce the $\mathrm{pH}$ and $\mathrm{HCO}_{3-}$ concentration of the $\mathrm{CBM}$ water. Both lower $\mathrm{HCO}_{3^{-}}$and higher $\mathrm{H}^{+}$activities favor the dissolution of calcite and dolomite in the vadose zone:

$$
(\mathrm{Ca}, \mathrm{Mg}) \mathrm{CO}_{3(\mathrm{~s})}+\mathrm{H}^{+} \leftrightarrow \mathrm{Ca}^{2+}, \mathrm{Mg}^{2+}+\mathrm{HCO}_{3}^{-}
$$

The resulting release of $\mathrm{Ca}^{2+}$ and $\mathrm{Mg}^{2+}$ is expected to reduce SAR values and prevent sodic conditions in the SDI fields (see equation 1).

\section{FIELD AND LABORATORY METHODS}

Data collection at the Headgate Draw site began in December 2007, with measurements being taken regularly since May 2008 (Figure 2). Initially, work was limited to nine MWs installed along the edges of the SDI fields (01MW-16MW; Figure 1) and four surface water sites. A total of 24 slug tests were conducted in eight of the nine wells in May 2009 to estimate the hydraulic conductivity of the alluvial aquifers below the site. Results from the slug tests were analyzed using the Bouwer and Rice (1976) method for unconfined aquifers. In October 2008, five additional MWs were installed in the middle of the SDI fields (wells 20MW-24MW) and subsequently developed. Water levels in the wells were measured once in December 2007 and monthly since May 2008. AquaTroll 200 pressure transducers (In Situ, Inc.), which record water level, temperature, and specific conductance every $6 \mathrm{hr}$, were installed in stages (Figure 2) in 10 of the MWs. Soil water tension is tracked using arrays of Irrometer Watermark (Model 200SS) granular matrix sensors, installed in October 2008, which were arranged in vertical profiles at depths of $0.2,0.5,1.0,1.5,2.0$, and $3.0 \mathrm{~m}(0.7,1.6,3.3,4.9$, 6.6 , and $9.8 \mathrm{ft}$ ) below the ground surface adjacent to $11 \mathrm{MW}, 20 \mathrm{MW}, 21 \mathrm{MW}, 23 \mathrm{MW}$, and $24 \mathrm{MW}$, respectively. The direction of vertical flow in the vadose zone is estimated for specific depth intervals by calculating the vertical total hydraulic head gradient $(\partial H / \partial z)$ :

$$
\frac{\partial H}{\partial z}=1-\frac{\partial P}{\partial z}
$$

where $H$ is the total hydraulic head (L), $z$ is elevation $(\mathrm{L})$, and $P$ is the pressure head (L). The pressure head is calculated by dividing the soil water matric potential ( -1 times the soil water tension) by the gravitational constant and the density of water. Net vertical movement is upward, downward, or neutral when $\partial \mathrm{H} / \partial \mathrm{z}$ is negative, positive, or zero, respectively.

Samples of surface water and groundwater were collected in December 2007 with quarterly collection beginning in May 2008 (Figure 2). Groundwater samples were collected after purging a minimum of three well volumes and waiting for water quality parameters to stabilize (U.S. Geological Survey, 2006). Surface water and groundwater samples were collected in HDPE bottles, except for rare earth element samples, which were collected in polypropylene bottles. Water quality parameters measured in the field using a flow-through cell include temperature, $\mathrm{pH}$, oxidation-reduction potential, specific conductance, dissolved oxygen (all measured by a YSI MPS 556 multiparameter unit), and turbidity (qualitatively estimated by visual observation). Soil water samples (collected in May and September 2009) were pulled from four sets of acidcleaned ceramic-tipped Irrometer suction lysimeters installed at depths of $0.5,1.0$, and $2.0 \mathrm{~m}(1.6,3.3$, and $6.6 \mathrm{ft}$ ) below the ground surface, adjacent to wells

Figure 1. (Upper) Aerial photograph of the Headgate Draw site showing the extent of agricultural fields, blocks of land augmented by subsurface drip irrigation (SDI), and locations of monitoring wells (MWs) and surface water sampling points. Potentiometric surface of the alluvial aquifer system based on data collected in October 2008; units are in meters above mean sea level. Aerial photograph taken on July 10, 2006, by the U.S. Department of Agriculture. (Lower) Idealized geologic cross section along transect AA'. Modified from Leopold and Miller (1954). SWPR = surface water-powder river; SWCR = surface water-crazy woman. 


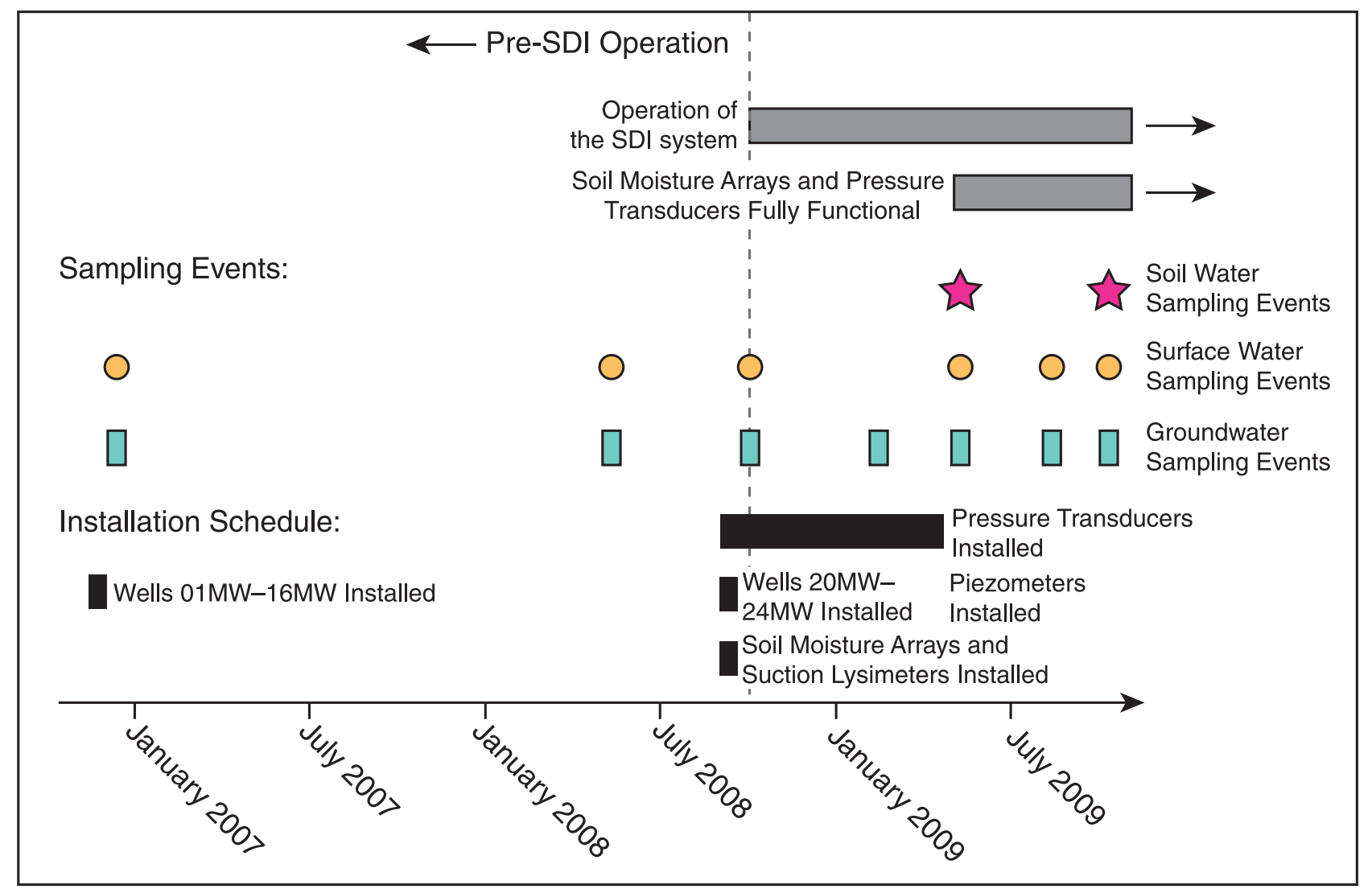

Figure 2. Timeline of significant events at the Headgate Draw site. SDI = subsurface drip irrigation.

$11 \mathrm{MW}, 21 \mathrm{MW}, 23 \mathrm{MW}$, and 24MW. All surface water and groundwater samples collected through the end of February 2009, and all soil water samples were filtered to less than $0.45 \mu \mathrm{m}$ in the field, and samples for metals analysis were immediately preserved to $\mathrm{pH}$ less than 2 with double-distilled $\mathrm{HNO}_{3}$. Surface water and groundwater samples collected after February 2009 were collected unfiltered and unpreserved, immediately placed on ice, and later filtered and preserved in the laboratory. All samples were shipped to the National Energy Technology Laboratory's analytical facilities in Pittsburgh, Pennsylvania, for chemical analysis.

The filtered water samples collected at the Headgate Draw site were analyzed for a variety of constituents. Concentrations of major elements $(\mathrm{Ca}, \mathrm{K}, \mathrm{Mg}, \mathrm{Na})$ and some trace elements (B, Ba, Fe, Li, Mn, S, Si, Sn, Sr, Ti, Zn) were measured on a PerkinElmer Optima 3000 inductively coupled plasma optical emission spectrometer, whereas concentrations of the remaining trace elements (Ag, Al, As, Cd, Co, Cr, Cu, Mo, Ni, Pb, Sb, $\mathrm{Se}, \mathrm{Th}, \mathrm{V}$ ) and rare earth elements (Ce, Dy, Er, Eu, Gd, Ho, La, Lu, Nd, Pr, Sc, Sm, Tb, Tm, Y, Yb) were determined using a PerkinElmer Elan 6100 inductively cou- pled plasma-mass spectrometer. Other analyses include major and minor anions by ion chromatography, alkalinity via titration, and TDS by mass of residue on evaporation at $180^{\circ} \mathrm{C}\left(356^{\circ} \mathrm{F}\right)$. Quality assurance-quality control (QA-QC) samples included field blanks, filter blanks, tubing blanks, pump blanks, replicate samples, matrix spikes, and reference materials. Although no QA-QC samples deviated significantly from acceptable limits, some samples exhibited large (>10\%) charge imbalances, and their results were discarded. Additional details on analytical methods, QA-QC results, and all raw geochemical data are presented in Geboy et al. (2011).

Five sediment cores spanning the unsaturated zone were collected by Geoprobe Systems (Salina, Kansas) at the locations of MWs 20MW through 24MW in October 2008. The cores were subsectioned in the laboratory by apparent changes in sediment texture or appearance, then air-dried, disaggregated, and sieved to less than $2 \mathrm{~mm}$. Sediment texture was determined on samples from cores at 21MW, 23MW, and 24MW by optical diffraction (Gee and Or, 2002) at the U.S. Geological Survey Unsaturated Zone Flow Laboratory. The distributions of naturally occurring salts in all cores were 
assessed by water extraction using a 1:20 soil/water ratio. Samples were combined with Milli-Q water, shaken for $20 \mathrm{~min}$ on a mechanical shaker, allowed to sit overnight, and then shaken again. Water extracts were centrifuged, filtered to $0.2 \mu \mathrm{m}$, and analyzed by ion chromatography at the U.S. Geological Survey in Denver. The U.S. Geological Survey standard reference samples were used to check analytical performance; measured concentrations of $\mathrm{SO}_{4}$ and $\mathrm{Cl}$ averaged 93 and $95 \%$, respectively, of expected concentrations.

\section{GEOCHEMICAL DATA ANALYSIS METHODS}

Mathematical geologists have demonstrated that water chemistry data are compositional; constituent concentrations provide information on the relative abundance of each element in a total magnitude (Otero et al., 2005). By nature, compositional data close to a sum (e.g., 100\% or $1000 \mathrm{~g} / \mathrm{L}$ in a low-salinity solution). Closure leads to a potentially spurious correlation between constituents and improper estimation of even univariate statistics (e.g., Filzmoser et al., 2009a, 2010). Several studies have demonstrated techniques to properly account for the compositional nature of water quality data in multivariate data analysis through the use of log ratio transformations (Buccianti and Pawlowsky-Glahn, 2005; Otero et al., 2005; Tolosana-Delgado et al., 2005). Following a similar approach, the raw chemical data in this study were transformed, before statistical treatment, using the centered log ratio (clr) of Aitchison (1986):

$$
\operatorname{clr}_{i}=\ln \frac{\mathrm{z}_{\mathrm{i}}}{\sqrt[D]{z_{1} z_{2} \cdots z_{D}}}
$$

and the isometric log ratio (ilr) of Egozcue et al., (2003):

$$
\mathrm{i} \mathrm{r}_{i}=\frac{1}{\sqrt{i(i+1)}} \ln \frac{z_{1} \ldots z_{i}}{z_{i}+1}
$$

where $z_{\mathrm{i}}$ is a part of the $D$-part subcomposition $z$ that is composed of $z_{1}, z_{2}, \ldots, z_{D}$, and for the ilr transformation, $i=1, \ldots, D-1$. Excellent explanations and significance of clr, ilr, and other log ratios are provided in Filzmoser et al. (2009a, 2010).

For this study, a 14-part subcomposition (B, Ba, Ca, $\mathrm{Cl}, \mathrm{Fe}, \mathrm{HCO}_{3}, \mathrm{~K}, \mathrm{Mg}, \mathrm{Mn}, \mathrm{Na}, \mathrm{SO}_{4}, \mathrm{Si}, \mathrm{Sr}$, and $\mathrm{H}_{2} \mathrm{O}$ [explained below]) was used for hierarchical cluster analysis and principal component analysis (PCA) to identify processes controlling site geochemistry and to identify the grouping of samples. The constituents comprising the subcomposition were selected because they contain no missing values and lack significant QA-QC issues. The masses of these constituents were summed to calculate the density of each sample, from which the mass of water $\left(\mathrm{H}_{2} \mathrm{O}\right)$ was determined and then added as the 14th part of the subcomposition. Following Templ et al. (2008), the cluster analysis was performed on ilr-transformed data. Because multivariate outliers were observed in the data, a robust minimum covariance determinant version of PCA was applied. The PCA was performed on ilr-transformed data and then back-transformed into clr space, the latter being easier to interpret (Filzmoser et al., 2009b). Methods to interpret PCA biplots for log-ratio transformed compositional data are discussed at length in Aitchison and Greenacre (2002). All compositional analyses were completed using the robCompositions package (Templ et al., 2010) for R, version 2.11.1 (R Development Core Team, 2010). Although these analyses were performed on a mixture of sample types (i.e., soil water, groundwater, and surface water), the samples are still considered homogeneous as their composition is derived from and controlled by similar processes.

\section{DISTRIBUTION AND CHANGES IN SOIL WATER, GROUNDWATER, AND SURFACE WATER QUANTITIES}

\section{Hydrogeologic Characterization}

The potentiometric surface of the unconfined alluvial aquifer system below the site, as determined from well water level measurements, indicates that groundwater generally flows northeast, parallel to the Powder River (Figure 1). Stream gauging data collected along the reach of the Powder River adjacent to the site indicate that during fall, gaining conditions exist, and that groundwater discharges to the river at parts of the site. Slug tests in wells screened in either the Kaycee or Lightning Formation yield fairly uniform saturated hydraulic conductivities that range from 73 to $240 \mathrm{~cm} /$ day $(2.4-8.0 \mathrm{ft} /$ day), as is typical for a silt or fine sand. These findings agree well with median sediment textures in soil cores collected in the vadose zone above MWs $21 \mathrm{MW}$ through 24MW; silt loam was the most common textural class in these samples. Darcy's Law calculations indicate that groundwater velocity in the unconfined aquifer systems ranges from 82 to $470 \mathrm{~cm} / \mathrm{yr}(32-185 \mathrm{in} . / \mathrm{yr})$. 
Figure 3. Vertical profiles of soil water tension at subsurface drip irrigation (SDI) and nonSDI sites measured during May 2009 and October 2009. Approximate depth of SDI emitters denoted by horizontal box at approximately $0.9-\mathrm{m}$ (3-ft) depth. The site number was based on the adjacent well number (i.e., site 20 is collocated with monitoring well 20 [20MW]).

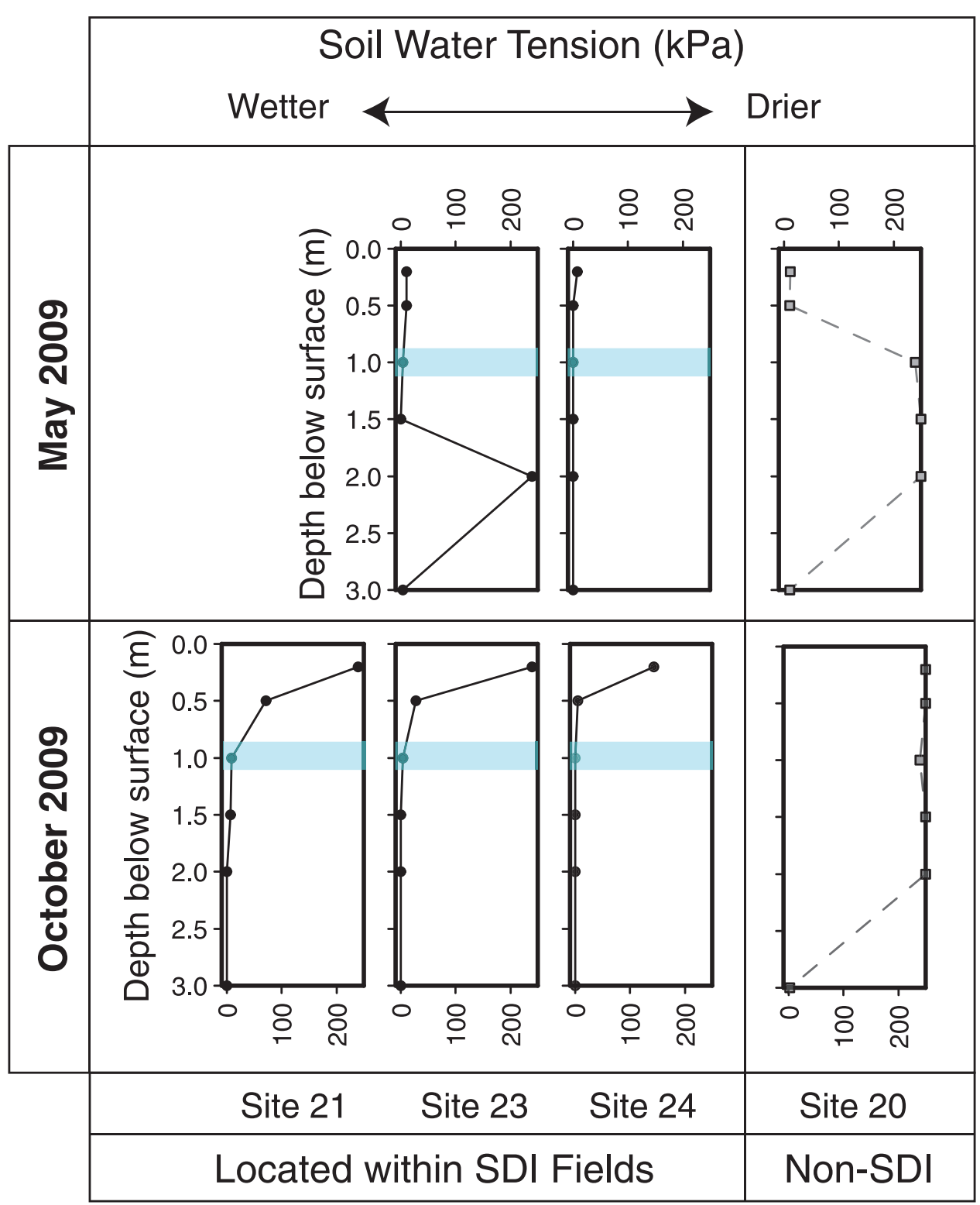

\section{Vadose Zone Hydrology and Response to Subsurface Drip Irrigation Operation}

In its first year of operation, the SDI system at the Headgate Draw site distributed approximately $2.9 \times 10^{5} \mathrm{~m}^{3}$ $\left(7.6 \times 10^{7} \mathrm{gal}\right)$ of CBM water across the irrigated parts of the site $\left(0.81 \mathrm{~km}^{2}\left[0.31 \mathrm{mi}^{2}\right]\right)$. This provided an average of $36 \mathrm{~cm}$ (14.2 in.) of irrigation, which is on the low side of the site's permitted capacity of 90 to $190 \mathrm{~cm}$ (36-72 in.), depending on the field. The total amount of precipitation received in the region during the same period was approximately $27 \mathrm{~cm}$ (10.7 in.), which primarily occurred in the spring (Western Regional Climate Center, 2010). Direct comparison between precipitation and SDI volumes should not be made because substan- tially more of the precipitation is lost to evapotranspiration in the upper few centimeters of the soil column than the injectate, which is emitted into the root zone.

To assess changes in soil moisture as a result of input of the additional water from the SDI system, vertical profiles of soil water tension from May and October 2009 were compared among sites that are actively being irrigated (SDI sites) and a site outside of the SDI blocks (non-SDI site). Figure 3 shows that the SDI sites are significantly closer to saturation (i.e., soil water tension approaching $0 \mathrm{kPa}$ ) than the non-SDI site, especially at depths closest to that of the SDI emitters $(\sim 0.9 \mathrm{~m}$ $[\sim 3 \mathrm{ft}])$. For both May and October 2009, all sites exhibited a zone of low soil water tension $(<10 \mathrm{kPa}$ $[<1.5 \mathrm{psi}])$ at a $3.0-\mathrm{m}(9.8-\mathrm{ft})$ depth. Depth to the water 
table for these sites and periods ranged from 2.7 to $4.0 \mathrm{~m}(8.7-13.1 \mathrm{ft})$, suggesting that the low water tensions at depth represent intersection with groundwater or the capillary fringe above the water table. Similar soil water tension profiles among sites 21, 23, and 24 suggest that although macropores and other heterogeneities exist at the site, their impacts on the measurement of system response were fairly limited during the study.

In May 2009, at the end of the peak precipitation for the region, conditions in the upper $0.5 \mathrm{~m}(1.6 \mathrm{ft})$ of the vadose zone were near saturation at all sites, likely as a result of meteoric infiltration. Similarly, maximum annual stream discharge and non-SDI well water levels were observed during this period (Figure 4). The values of $\partial H / \partial z$ calculated for the depth interval of 0.2 to $1.0 \mathrm{~m}(0.7-3.3 \mathrm{ft})$ at sites adjacent to wells $23 \mathrm{MW}$ and $24 \mathrm{MW}$ at this time were near zero $(<0.2)$, implying little net water movement in the vadose zone above the emitters during this period. In October 2009, near-surface conditions in the soil were substantially drier. The lower water contents are attributed to the minimal precipitation and high evapotranspiration rates of the previous summer. Minimum well water levels and low stream flows were also observed during this period (Figure 4). The large vertical soil water tension gradient above the depth of the SDI emitters at this time produced significant hydraulic head gradients (less than -29 to -17), indicating a net upward movement of water in the upper $1.0 \mathrm{~m}(3.3 \mathrm{ft})$ of the soil profile. Near-constant soil water tension in the lower $2 \mathrm{~m}(6.6 \mathrm{ft})$ of the SDI sites produced downward gravity-driven movement during these periods $(\partial H / \partial z$ near 1$)$. These findings suggest that above the depth of the emitters, the direction of soil water movement in the SDI areas changes seasonally. In contrast, a continuous downward movement of water is predicted from the emitters toward the water table. The downward movement of water during the winter months is expected to increase when the upper several decimeters of the soil are frozen, impeding upward flow.

Soil pits dug from the surface to down to the depth of the drip tape were used to investigate changes to soil structure and permeability during the SDI operation. Soils in non-SDI areas of the Headgate Draw site exhibit a subangular blocky structure. A notable breakdown in this structure was observed in a 15-cm (6-in.) radius around the drip tape, suggesting a limited disintegration of the soil structure and lower permeability. Once developed, no significant movement of this zone was observed.
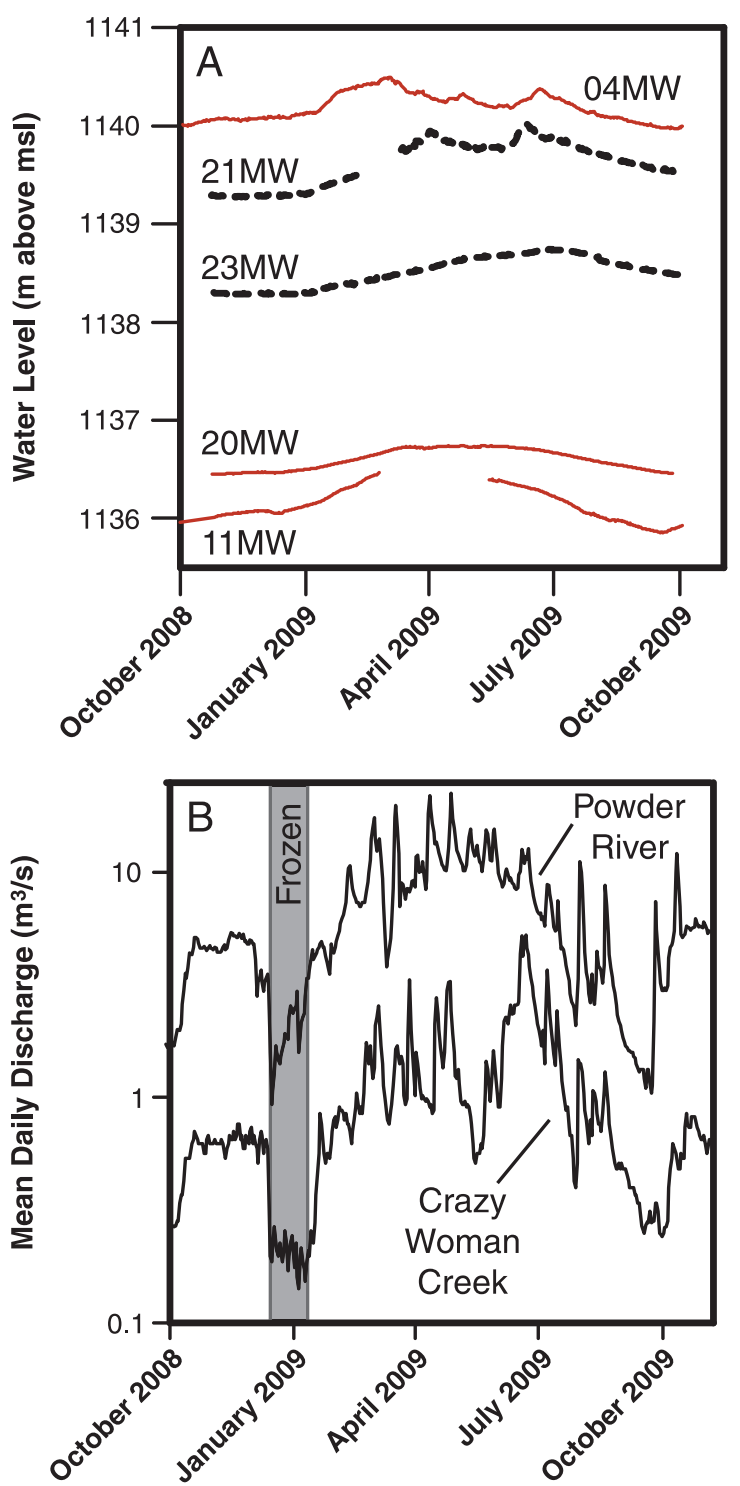

Figure 4. (A) Time series of water level from pressure transducers in five monitoring wells (MWs) screened in the alluvial aquifer at the Headgate Draw site during the first year of the subsurface drip irrigation (SDI) operation. Dashed lines indicate that the MW is located within the active SDI field. Solid lines indicate MW located outside of the SDI area. (B) Mean daily discharge of the Powder River (measured $25 \mathrm{~km}$ [15.5 mi] downstream) and Crazy Woman Creek (measured $6 \mathrm{~km}$ [3.7 mi] upstream) during the same period as (A) (data from U.S. Geological Survey, 2010).

\section{Changes in Groundwater Storage}

To track water transport from the SDI system into the alluvial groundwater aquifers, well water levels were monitored (Figure 4A). Near-continuous well water level time series data for the first year of SDI operation were available for five monitoring wells: 04MW, $11 \mathrm{MW}$, 
Table 1. Comparison of Changes in Well Water Level Relative to Measurements in October 2008 for Wells in SDI Fields (SDI) and Outside of SDI Fields (Non-SDI)*

\begin{tabular}{|c|c|c|c|c|c|}
\hline Type & $\mathrm{n}$ & February $2009(\mathrm{~cm})$ & May 2009 (cm) & July 2009 (cm) & October $2009(\mathrm{~cm})$ \\
\hline SDI** wells & 6 & $0.12 \pm 0.53$ & $0.38 \pm 0.11$ & $0.39 \pm 0.16$ & $0.16 \pm 0.14$ \\
\hline Non-SDI wells & 7 & $0.14 \pm 0.27$ & $0.30 \pm 0.08$ & $0.26 \pm 0.09$ & $0.01 \pm 0.13$ \\
\hline$P$ & & & & & 0.058 \\
\hline
\end{tabular}

*Values indicate mean \pm standard deviation; all data were collected within a 48-h period for each event. The value of $P$ was shown for one-way Mann-Whitney $\mathrm{U}$ test between SDI and non-SDI data.

**SDI = subsurface drip irrigation.

20MW (all non-SDI), 21MW, and 23MW (both SDI). These well water level time series were compared against daily mean discharge measurements (Figure 4B) for the Powder River (measured 25 km [15.5 mi] downstream of the Headgate Draw site) and Crazy Woman Creek (measured $6 \mathrm{~km}$ [3.7 mi] upstream; data from U.S. Geological Survey, 2010). The water levels for the three non-SDI wells reached a maximum in the spring (March-May) because of meteoric recharge; for the two SDI wells, the highest levels were observed in mid- to late summer. Net water levels after the first year of SDI operation (October 2008-October 2009; Figure 4) were positive (indicating net recharge) in the SDI wells but were near zero in non-SDI wells (discussed in further detail below). The increased water levels in $21 \mathrm{MW}$ and 23MW are attributed to input from the SDI system. Water levels in 21MW (SDI) and 04MW (nonSDI) both exhibited erratic abrupt changes, suggesting that similar processes were acting on these two proximal wells. Maximum water levels in 21MW corresponded to high discharge events in Crazy Woman Creek (suggesting a possible surface water-groundwater interaction), whereas the short pulses of maximum water levels in 04MW did not correspond as strongly to corresponding peaks in the stream discharge. However, the monthly average water levels in $04 \mathrm{MW}$ correlated significantly with those for $11 \mathrm{MW}(r=0.92, P<0.01)$ but not for 21MW ( $r=0.30, P=0.16)$; monthly average water levels correlate significantly between the SDI wells, $21 \mathrm{MW}$ and 23MW ( $r=0.99, P<0.01)$. Patterns seen in well water levels across the site suggest that although some similar processes (infiltration and surfacewater interaction) impact multiple wells, water levels in the SDI wells are characteristically distinct from the non-SDI wells. Significant correlations were found between water levels in 11MW and 20MW with flow in the Powder River $(r>0.75, P<0.05)$ and between water levels in 20MW, 21MW, and 23MW and flow in
Crazy Woman Creek $(r>0.65, P<0.05)$. It is unclear whether these relationships indicate significant surface water-groundwater exchange or instead similar responses to precipitation patterns.

To assess site-wide seasonal changes to groundwater levels as a result of SDI operation, well water levels for all 14 MWs measured in winter (February 2009), spring (May 2009), summer (July 2009), and fall (October 2009) were compared with conditions from the start of SDI operation in October 2008 (Table 1). For reference, a similar comparison was also made for well water levels from non-SDI wells. Comparisons of changes in well water levels after $1 \mathrm{yr}$ of operation between SDI and non-SDI wells were examined for statistical significance using a one-way Mann-Whitney $U$ test for unpaired data. Results from the test show that the water levels between SDI wells and non-SDI wells were borderline for being statistically different $(P=0.058)$. During the period of SDI operation, water levels had increased $16 \mathrm{~cm}$ (6.3 in.) on average in wells within SDI fields, whereas water levels from non-SDI wells had not changed significantly $(P<0.05)$. The latter finding is significant because the non-SDI wells are located in areas of both uncultivated rangeland and nonirrigated agricultural fields, indicating that vegetation contrasts did not play significantly into these well water level variations. The water level rise in the porous media of the aquifer was multiplied by the specific yield for fine sand $(\sim 20 \%)$ to provide an estimate of change in groundwater storage of $3.2 \mathrm{~cm}$ (1.3 in.). However, this likely underestimates the increase in groundwater storage because of increased lateral flow away from areas where water levels are rising. For instance, 16MW (an SDI well) is located between two SDI blocks, approximately $6 \mathrm{~m}$ $(\sim 20 \mathrm{ft})$ from the edge of the nearer block (Figure 1). Water levels in this well increased $22 \mathrm{~cm}$ (8.6 in.) during the first year of SDI operation, indicating that groundwater flow away from the SDI fields is occurring in this area. 


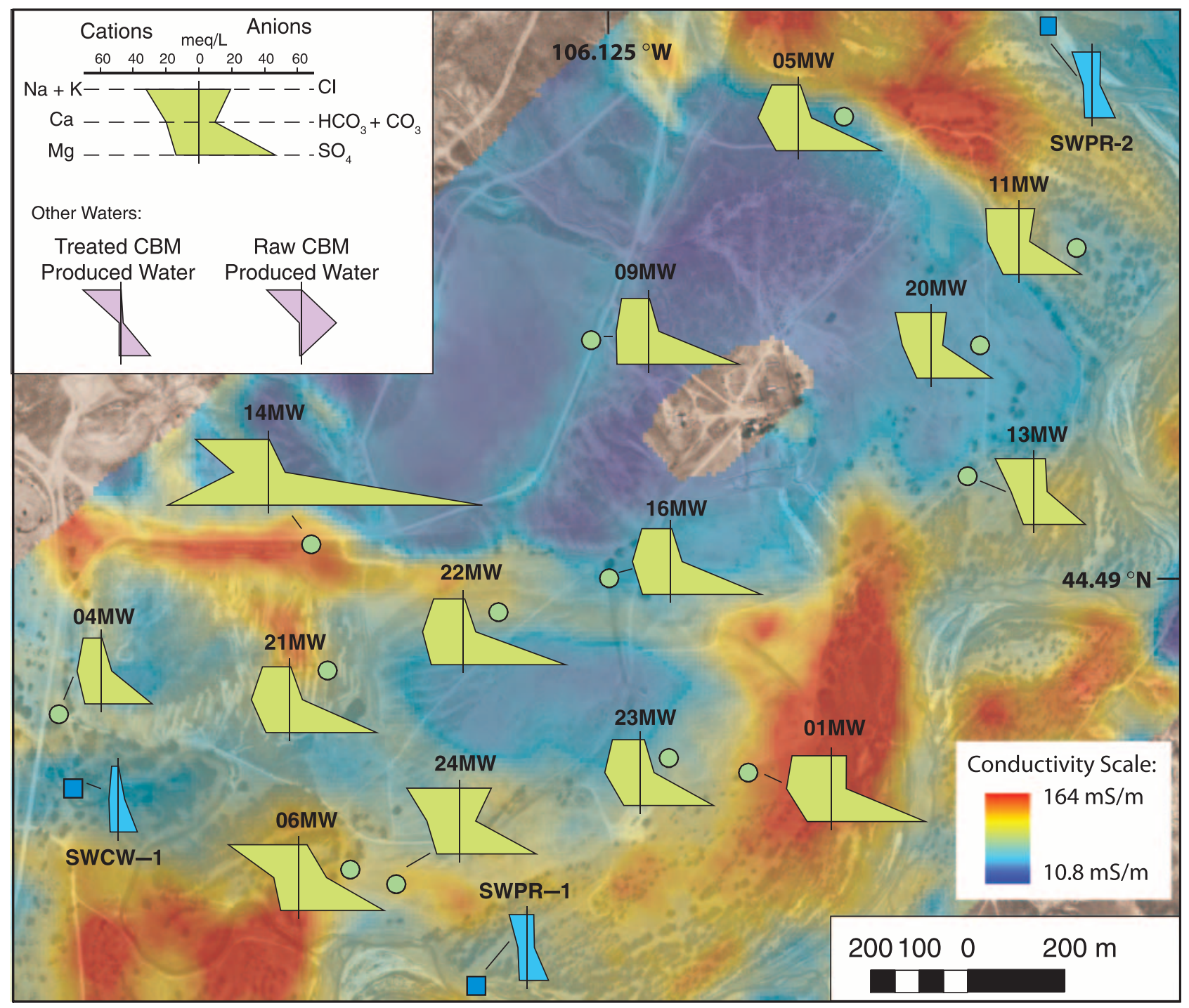

Figure 5. An aerial photograph of the site draped with conductivity from helicopter electromagnetic surveys of the site. Warmer colors denote more conductive materials such as clay, salts, and high total dissolved solids (TDS) water. Stiff diagrams denote the composition of coalbed methane (CBM) water (pink), treated CBM water (injectate; pink), groundwater (green), and surface water samples (aqua) collected in October 2008. SWPR = surface water-powder river; SWCR = surface water-crazy woman.

\section{GEOCHEMICAL CHARACTERIZATION AND INITIAL IMPACTS TO SOIL WATER, GROUNDWATER, AND SURFACE WATER QUALITY}

\section{Characterization of Site Waters}

Pre-SDI major ion groundwater and surface water composition is illustrated in Figure 5. Across much of the site, groundwaters are $\mathrm{Ca}-\mathrm{SO} 4$ dominated (Figure 5; Table 2), reflecting the influence of gypsum dissolution via:

$$
\mathrm{CaSO}_{4} \cdot 2 \mathrm{H}_{2} \mathrm{O}_{(\mathrm{s})} \leftrightarrow \mathrm{Ca}^{2+}+\mathrm{SO}_{4}^{2-}+2 \mathrm{H}_{2} \mathrm{O}
$$

and contain TDS concentrations (1350-11,300 mg/L) above what is typically considered potable for humans $(<1200 \mathrm{mg} / \mathrm{L})$. The control of major ion chemistry of the site groundwaters by gypsum and/or anhydrite, calcite, and dolomite is suggested by near-equilibrium conditions, as indicated from thermodynamic modeling using PHREEQC (Parkhurst and Appelo, 1999). Water samples from the Powder River and Crazy Woman Creek are markedly different. The $\mathrm{Na}-\mathrm{SO}_{4}$-dominant character of the Powder River has been attributed to contributions of soluble salts derived from Tertiary sedimentary rocks that are present in the eastern part of the basin (Clark and Mason, 2006). Conversely, the Ca, 
Table 2. Range of Water Quality Parameters and Major Ion Composition for Samples Collected at the Headgate Draw Site

\begin{tabular}{|c|c|c|c|c|c|c|c|}
\hline Parameter & Units & CBM* Water & Injectate & Soil Water & Groundwater & Crazy Woman Creek & Powder River \\
\hline pH & & 7.3-7.7 & $5.1-7.9$ & $7.3-8.1$ & $6.5-8.8$ & $7.8-9.1$ & $7.5-9.3$ \\
\hline ORP* & MV & $(-) 116-183$ & $329-696$ & $N A^{*}$ & (-)19-(-)162 & $65-219$ & 49-205 \\
\hline Sp. Cond. * & $\mu \mathrm{S} / \mathrm{cm}$ & 2040-2170 & $2100-2390$ & NA & $2732-9710$ & $540-1820$ & $840-2190$ \\
\hline TDS* & $\mathrm{mg} / \mathrm{L}$ & $1380-2790$ & $1200-1700$ & NA & $1350-11,300$ & $390-1650$ & $620-1620$ \\
\hline SAR* & & $4.3-20.8$ & $12.4-23.4$ & $0.32-27.5$ & $2.3-12.5$ & $1.2-2.3$ & $2.0-6.3$ \\
\hline Type & & $\mathrm{Na}-\mathrm{HCO}_{3}$ & $\begin{array}{l}\mathrm{Na}-\mathrm{SO}_{4} \text { to } \\
\mathrm{Na}-\mathrm{HCO}_{3}\end{array}$ & $\begin{array}{c}\mathrm{Ca}^{-} \mathrm{SO}_{4} \text { to } \\
\mathrm{Na}-\mathrm{SO}_{4}\end{array}$ & $\begin{array}{c}\mathrm{Ca}-\mathrm{SO}_{4}, \mathrm{Mg}_{-} \mathrm{SO}_{4} \\
\text { or } \mathrm{Na}-\mathrm{SO}_{4}\end{array}$ & $\begin{array}{c}\mathrm{Ca}-\mathrm{SO}_{4} \text { to } \\
\mathrm{Mg}^{-\mathrm{SO}_{4}}\end{array}$ & $\begin{array}{c}\mathrm{Na}-\mathrm{SO}_{4} \text { to } \\
\mathrm{Mg}^{-} \mathrm{SO}_{4}\end{array}$ \\
\hline
\end{tabular}

${ }^{*} \mathrm{CBM}=$ coalbed methane; ORP = oxidation-reduction potential; Sp. Cond. = specific conductance; TDS = total dissolved solids; $\mathrm{SAR}=$ sodium adsorption ratio; NA = not available.

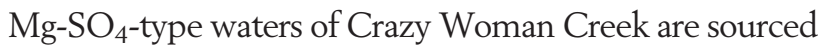
from the Bighorn Mountains to the west, where salt accumulation (and hence, enrichment of $\mathrm{Na}-\mathrm{Cl}$ ) is limited (Clark and Mason, 2006). Groundwater samples collected from wells adjacent to the $\mathrm{Na}-\mathrm{SO}_{4}$-type Powder River water (e.g., 06MW and 13MW) and $\mathrm{Ca}, \mathrm{Mg}$ $\mathrm{SO}_{4}$-type Crazy Woman Creek water (i.e., 04MW) exhibit major ion patterns similar to the nearest surface water body, suggesting surface water-groundwater mixing in these areas. Water samples collected from $14 \mathrm{MW}$ contain high concentrations of TDS and $\mathrm{Mg}$ (Figure 5). This unique signature may result from seasonal input of salt from upland-derived runoff down Headgate Draw or ion exchange reactions.

\section{Multivariate Data Analysis}

Additional information about the composition of Headgate Draw waters was provided from hierarchical cluster analysis of the isometrically log-transformed subcomposition of data for samples collected in October 2008. The resulting dendrogram (Figure 6) plots the longest Aitchison distance required to form clusters from the individual samples or groups of samples. Linkages (i.e., the horizontal lines connecting clusters) formed at a lower height indicate that the individual samples being clustered are more similar than those for clusters whose linkages occur at a greater height. Therefore, the sample of CBM water from that sampling event is the most unlike any other sample, and samples from $21 \mathrm{MW}$ and $22 \mathrm{MW}$ are the most similar to each other relative to any other pair. The results also indicate that the site groundwaters are chemically distinct from the surface waters and the CBM water. The cluster analysis indicates that the groundwater samples compositionally fall into three different groups: group 1 wells are in a flow path closest to the Powder River and Crazy Woman Creek (01MW, 06MW, 11MW, 13MW, 20MW, and 24MW); group 2 wells are in a flow path through the center of the Moorcroft Terrace $04 \mathrm{MW}, 05 \mathrm{MW}$, $16 \mathrm{MW}, 21 \mathrm{MW}, 22 \mathrm{MW}$, and 23MW); and group 3 wells are located near upland drainages (09MW and 14MW).

The PCA of the log-ratio transformed data for all sites and samples up through the first year of SDI operation

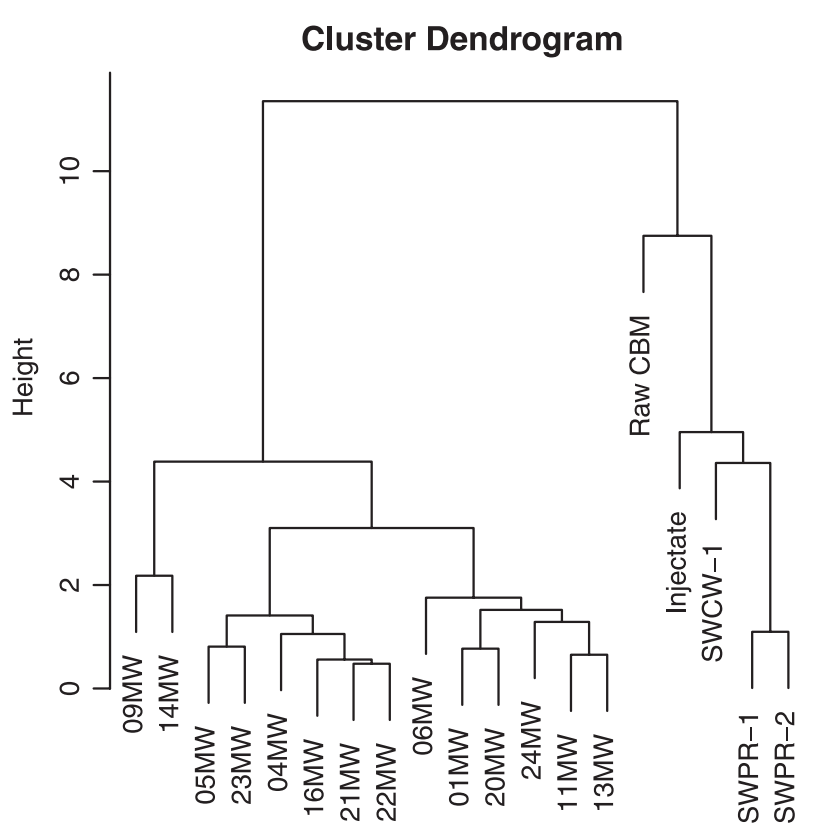

Figure 6. A hierarchical cluster dendrogram showing clustering based on complete linkages of centered isometric log-ratio transformed data between samples or groups of samples using data from the start of the subsurface drip irrigation (SDI) operation (October 2008). The height of the linkages (i.e., horizontal lines) indicates the relative distance between samples or groups of samples being clustered. $\mathrm{CBM}=$ coalbed methane; TDS = total dissolved solids; SWPR = surface water-powder river; SWCR = surface water-crazy woman. 


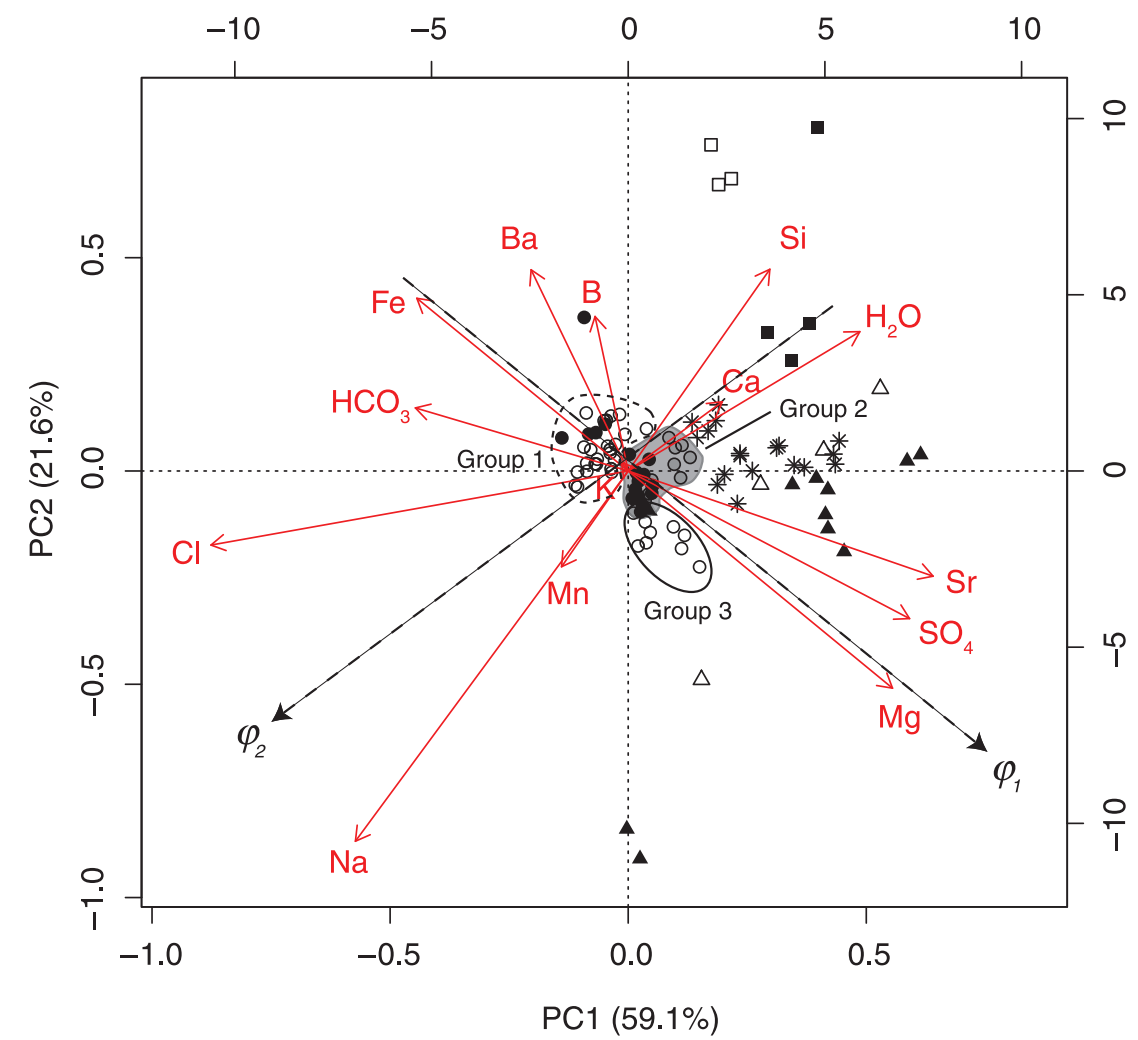

Figure 7. Principal component analysis biplot showing solute loadings and sample scores for centered log-ratio (clr) transformed data of a 14-part subcomposition for water chemistry data up through the first year of subsurface drip irrigation (SDI) operation. The total variance of the data accounted for by each of the components is shown in parentheses. Groundwater samples were grouped based on results from the cluster analysis (see Figure 6). Links $\left(\varphi_{1}, \varphi_{2}\right)$ between loading vectors are shown as dashed lines. $\mathrm{CBM}=$ coalbed methane.
- Non-SDI Groundwater
- SDI Groundwater
$\triangle$ Non-SDI Soil Water
- CBM Water
- SDI Soil Water
- Injectate
* Surface Water

at the Headgate Draw site also shows separation between groundwater groups (Figure 7). The PCA biplot graphs the sample scores and solute loadings as a function of the first two principal components, which account for more than $80 \%$ of the total variance in the data. For clr-transformed data, the origin of the biplot corresponds to a robust estimator of the geometric mean of the data set. The square of the distance from the origin of the biplot to the tip of a loading vector is approximately equal to a robust estimate of variance for the log-centered solute it represents (Buccianti and Pawlowsky-Glahn, 2005). For example, elements such as $\mathrm{Na}, \mathrm{Cl}$, and $\mathrm{Mg}$ exhibit the largest log-centered variance within the data set. Projection of the factor loadings onto the $\mathrm{x}$ axis indicates that the first principal component is controlled by high positive loadings of $\mathrm{Sr}, \mathrm{Mg}$, and $\mathrm{SO}_{4}$ and strong negative loadings of $\mathrm{Na}$ and Cl. Similarly, projection of loadings onto the y axis indicates that the second component exhibits a large positive influence from $\mathrm{Ba}$ and $\mathrm{Si}$ and negative loadings from $\mathrm{Na}$ and $\mathrm{Mg}$. Because the squared distance between the vertices of two vector loadings is roughly equal to the robustly estimated variance of the log ratio of the same two variables, the proximal location of loading vectors suggests that the solutes may be proportional and may have a stoichiometric relationship. For instance, loading vectors for $\mathrm{Mg}, \mathrm{Sr}$, and $\mathrm{SO}_{4}$ are located proximally with one another and may be similarly derived from the dissolution of subsurface salts and subsequent ion exchange of $\mathrm{Ca}$ and $\mathrm{Na}$ for $\mathrm{Mg}$ and $\mathrm{Sr}$ (Figure 7) (Brinck and Frost, 2007). Likewise, the orthogonal relationship between $\mathrm{Ca}$ and a nearly straight line between $\mathrm{SO}_{4}$ and $\mathrm{HCO}_{3}$ may indicate that some of the Ca generated from gypsum dissolution (see equation 6 ) is removed through calcite precipitation (see equation 2), leading to a decrease in $\mathrm{HCO}_{3}$ concentrations or is lost to ion exchange, such that little variance exists in $\mathrm{clr}$ values of $\mathrm{Ca} / \mathrm{SO}_{4}$ and $\mathrm{Ca} / \mathrm{HCO}_{3}$.

In PCA biplots of log-ratio transformed data, links between loading vectors are typically more important than the vectors themselves (Aitchison and Greenacre, 2002). Two primary links were visually identified in this data set (Figure 7): $\operatorname{link} \varphi_{1}$, which trends away from associations of $\mathrm{Fe}, \mathrm{Ba}$, and $\mathrm{HCO}_{3}$ toward loadings of 
$\mathrm{Mg}, \mathrm{Sr}$, and $\mathrm{SO}_{4}$; and link $\varphi_{2}$, which trends from associations of $\mathrm{Si}$ and $\mathrm{H}_{2} \mathrm{O}$ (i.e., water purity or lack of solutes) to input from $\mathrm{Na}, \mathrm{Cl}$, and $\mathrm{Mn}$. Because the two links are nearly orthogonal, they are likely uncorrelated. We interpret link $\varphi_{1}$ as trending from reduced Eh conditions where $\mathrm{Fe}$ is soluble, $\mathrm{HCO}_{3}$ is generated from $\mathrm{SO}_{4}$ reduction, and low $\mathrm{SO}_{4}$ conditions give rise to increased barite solubility (and thus Ba solubility) to input of young oxidized water that has picked up solutes $\left(\mathrm{Mg}, \mathrm{Sr}\right.$, and $\left.\mathrm{SO}_{4}\right)$ from the dissolution of salts. These interpretations are consistent with the observation of reducing organic-rich sediments in cores from group 1 wells (reduced part of the link) and the highTDS relatively Mg-rich group 3 waters located near the mouth of upland drainages, where abundant gypsum and other soluble minerals have been observed in outcrop (oxidized part of the link). Link $\varphi_{2}$ is interpreted as a trend from dilute conditions to an $\mathrm{Na}-\mathrm{Cl}$-rich evaporated system. Data for samples from the upgradient 04MW well plot closer to the more dilute end-member of link $\varphi_{2}$, whereas samples from the $01 \mathrm{MW}$ plot closer to the evaporated end-member. As evidence for the validity of the PCA results, samples from the Powder River plot as a mixture of the dilute end of $\operatorname{link} \varphi_{2}$ and the salt dissolution part of link $\varphi_{1}$, whereas samples from Crazy Woman Creek plot along link $\varphi_{2}$, indicating the influence from salt inputs. Likewise, the biplot indicates that $\mathrm{CBM}$ water is associated with the reducing environment and more pristine part of the links, whereas the injectate, which has been readily oxidized in the open-air impoundment, plots near link $\varphi_{2}$. This model provides a framework for the controls on the composition of groundwater and surface waters at the Headgate Draw site.

\section{Composition and Impact of SDI Waters}

Samples of CBM-produced water piped to the Headgate Draw site are typical for the PRB in that they are circumneutral $\mathrm{pH} \mathrm{Na}-\mathrm{HCO}_{3}$-dominated waters that exhibit a high SAR and moderate TDS (Figure 5; Table 2) (Rice et al., 2002). Despite being a mixture from several wells, the CBM water used at the site shows very little variability with time in terms of specific conductance $(\sim 6 \%)$ and ionic composition (Table 2$)$. This invariance of composition with time suggests that any potential changes in the SDI operation and/or stimulation has little impact on the composition of waters received at the site. The atmospheric oxidation, filtration, and acidification via $\mathrm{H}_{2} \mathrm{SO}_{4}$ of the $\mathrm{CBM}$ water before injection cause a shift to a more acidic $\mathrm{SO}_{4}$-rich composition (injectate data in Table 2; Figure 5) and reduce concentrations of redox-sensitive trace elements such as $\mathrm{Fe}$ and As (Geboy et al., 2011). The concentrations of most constituents in the injectate are several orders of magnitude lower than local groundwater samples, although SAR values are much higher (Table 2) (Geboy et al., 2011). For all injectate samples, trace element concentrations are below EPA maximum contaminant levels, typically by 1 to 3 orders of magnitude. The relatively dilute nature of these waters suggests that infiltration and direct mixing of treated CBM water with site groundwater would produce a shift to lower TDS Narich groundwater below the SDI fields. However, the composition of the injectate is greatly modified as it is introduced to the vadose zone.

To investigate geochemical changes of the injectate in the vadose zone, soil water samples were collected, when possible, at three depths $(0.5,1.0$, and $2.0 \mathrm{~m}$ [1.6, 3.3, and $6.6 \mathrm{ft}]$ ) from four sampling locations. Soil water samples exhibit significant variations in major ion composition (from $\mathrm{Ca}-\mathrm{HCO}_{3}$ to $\mathrm{Mg}-\mathrm{SO}_{4}$ ) among sites and with depth (Figure 8). None of the soil water samples collected in SDI areas are compositionally similar to $\mathrm{Na}-\mathrm{SO}_{4}$ - and/or $\mathrm{Na}-\mathrm{HCO}_{3}$-type injectate (cf. Table 2; Figure 7). Geochemical modeling using PHREEQC indicates that although the injectate is typically undersaturated with respect to calcite, dolomite, anhydrite, and gypsum (SI values typically -2.5 to -1 ), samples of soil water are slightly saturated with respect to the carbonate minerals and at near equilibrium with gypsum and anhydrite. This suggests that mineral dissolution is a source of $\mathrm{Ca}$ and $\mathrm{Mg}$ in the soil water. These reactions serve to buffer the SAR of the incoming injectate (see equation 2). This is most telling in soil waters collected closest to the depth of the emitter $(1.0 \mathrm{~m}[3.3 \mathrm{ft}])$, which contain SAR values $50 \%$ to $80 \%$ lower than the incoming injectate (Table 2). Although cation exchange is prevalent in the smectite-rich soils of the PRB (Healy et al., 2008), Na concentrations of injectate and soil water collected at the $1.0-\mathrm{m}(3.3-\mathrm{ft})$ depth were not statistically different $(P=0.40$; Mann-Whitney $U$ test), indicating that little $\mathrm{Na}$ is lost or gained near the emitters. The highest TDS concentrations measured in soil water samples from the site, which typically exceed injectate or groundwater concentrations (Table 2), were measured in soil water samples collected at depths of 1.0 and $2.0 \mathrm{~m}$ (3.3 and $6.6 \mathrm{ft}$ ) below ground surface. The highest solute concentrations, measured in soil water near $24 \mathrm{MW}$, are in a zone of high electromagnetic 


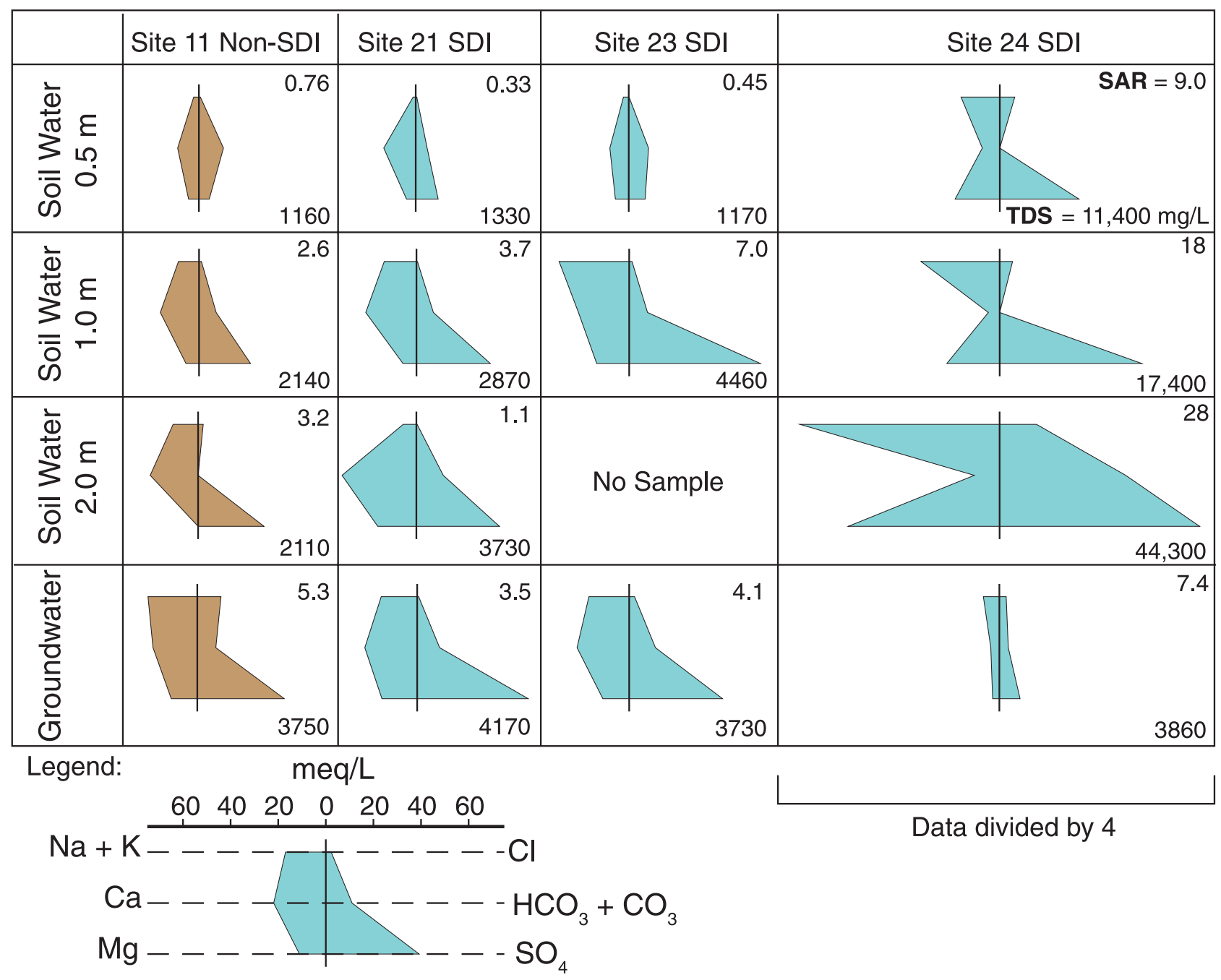

Figure 8. Stiff diagrams showing the major ion composition of soil water and groundwater samples collected in May 2009. Bicarbonate data were estimated based on charge balance of other major ions. SAR = sodium adsorption ratio; SDI = subsurface drip irrigation; TDS = total dissolved solids. Raw data published in Geboy et al. (2011).

(EM) conductivity, based on geophysical surveys (Sams et al., 2010) (Figure 5). The high EM conductivities are consistent with salts in the subsurface. Lower solute concentrations in soil water samples collected at a depth of $0.5 \mathrm{~m}(1.6 \mathrm{ft})$ likely result from dilution by infiltrating precipitation.

Examination of the PCA biplot shows that most soil water samples from the Headgate Draw site appear to be a mixture of the dilute water part of link $\varphi_{1}$ (which probably represents both input of meteoric infiltration and the injectate) and the shallow salt dissolution end of link $\varphi_{2}$ (Figure 7). However, three of the soil water samples plot close to the y axis, indicating significant control by evaporation and dissolution of vadose zone salts. Further support of evaporation as an important control of solutes is the elevated $\mathrm{Cl}$ concentration (as much as $2200 \mathrm{mg} / \mathrm{L}$ ) in soil water samples collected in the capillary fringe above the water table. Despite variations between samples of the control of evaporation on ion chemistry, all soil waters at the site appear to be chemically controlled by dissolution of native subsurface salt.

Water-extractable anion data from cores collected near the start of the SDI operation indicate the presence of substantial quantities of native salts in the vadose zone (Figure 9). Concentrations of extractable anions were generally lowest at the surface and near the water table in the capillary fringe, coinciding with the zones of maximum soil water content before the SDI operation (using site 20 in Figure 3 as an analog). Sulfate was the most abundant anion, and concentrations in 1:20 water extracts were as great as $1340 \mathrm{mg} / \mathrm{L}$ (Figure 9). 

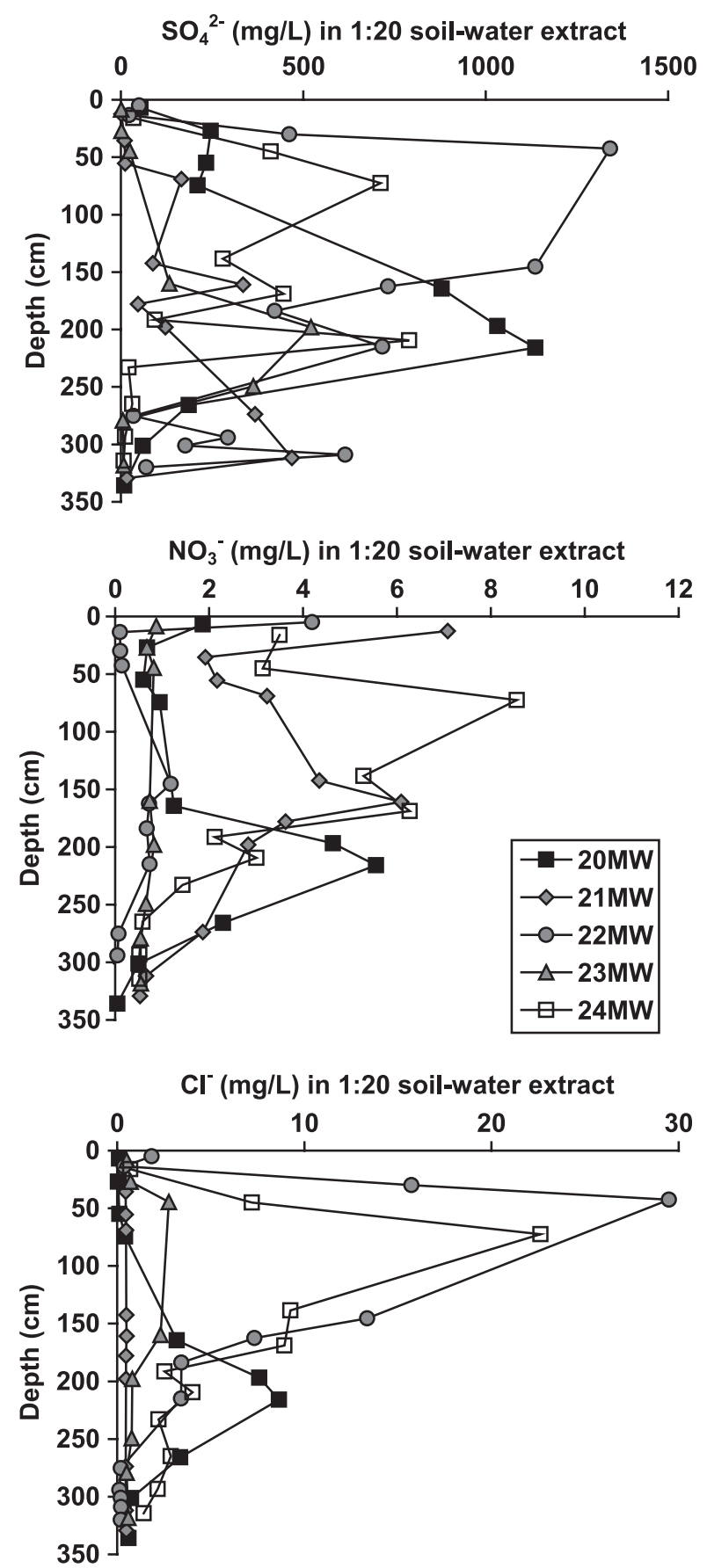

Figure 9. Variations in concentrations of extractable anions with depth from cores collected during installation of monitoring well $21 \mathrm{MW}$ to $24 \mathrm{MW}$. These figures demonstrate the potential availability of $\mathrm{SO}_{4}, \mathrm{Cl}$, and $\mathrm{NO}_{3}$ from native salts to infiltrating waters.

Assuming gypsum is the source of all $\mathrm{SO}_{4}$ measured in the extractions, concentrations of as much as $38 \mathrm{mg} / \mathrm{g}$ of gypsum are present in the sediment, although other $\mathrm{SO}_{4}$ minerals could be present. Water-extractable $\mathrm{NO}_{3}$ and $\mathrm{Cl}$ were also present, and cores from $22 \mathrm{MW}$ and
24MW show a distinct $\mathrm{Cl}$ bulge in the vicinity of 0.50 - to $0.75-\mathrm{m}$ (1.6- to $2.5-\mathrm{ft})$ depth, just above the level of the drip tape (Figure 9). However, the remainder of the extractable anion data shows substantial variability, possibly reflecting the complexity of sediment and solute distribution in this alluvial setting. Local microtopography, textural variability from buried channels, and the distribution of floodwaters from gullies and washes upslope could all influence the chemistry and quantity of water available for native salt emplacement. One apparent disparity is the elevated TDS concentrations measured in lysimeters near site 24 relative to other sites (Figure 8), coinciding with a lack of anomalous extractable salts from a nearby soil core (Figure 9). One possible explanation is mixing of injectate with highly evaporated native soil water, which is supported by the indication of significant evaporation in the PCA biplot for the two samples from site 24 with the highest TDS concentrations (Figure 7).

To identify changes in concentrations and relative abundance of dissolved ions with time as a result of SDI operation, groundwater specific conductance for postSDI sampling events was compared between SDI and non-SDI sites relative to October 2008 conditions. Potential causes for these changes, as described in the previous text, include input of injectate, meteoric infiltration, surface water-groundwater mixing, ion exchange, evaporation, mineral precipitation, and dissolution of vadose zone salts. To examine for differences in solute input to groundwater as a response to SDI input, net changes in specific conductance since the start of the SDI operation were calculated for all wells in which pressure transducers had been installed. Changes in specific conductance were determined for periods in May, August, and October of 2009. Comparisons of quantile-quantile plots for the SDI versus non-SDI wells showed that other than a couple of outliers (discussed below), changes in specific conductance were fairly similar $(<100 \mu \mathrm{S} / \mathrm{cm})$ between SDI and nonSDI wells. In addition, no large shifts in groundwater chemistry were observed in the PCA biplot for the three groundwater groups (Figure 7). This suggests that, in general, the groundwater in the vicinity of SDI wells had not significantly responded to increased input from infiltrating soil water and/or injectate. This may indicate that solute transport occurs more slowly than water transport or that the volume of injectate added to the groundwater was too small to dramatically affect its composition during the first year of the SDI operation. However, water from the three wells (two 
SDI and one non-SDI) showed a more than 5\% change in specific conductance in the approximately 1-yr period since initiation of the SDI system: 04MW (23\% increase), $21 \mathrm{MW}$ (26\% increase), 24MW (18\% decrease).

Major ion concentrations for water samples from 04MW (non-SDI well) and 21MW (SDI Well) showed dilution (decrease in $\mathrm{Cl}, \mathrm{SO}_{4}, \mathrm{Ca}$, and $\mathrm{Na}$ ) in the wet season (May 2009) relative to October 2008 followed by 25 to $75 \%$ enrichments in most major ions through the summer and into the fall (Figure 10). Samples from $21 \mathrm{MW}$ showed the largest solute concentration increases in $\mathrm{Cl}$ and $\mathrm{Na}$ between May and November 2009 ( 75 and 45\%, respectively), suggesting input from an evaporated water source, whereas samples from 04MW showed the largest increases in $\mathrm{Mg}, \mathrm{Ca}, \mathrm{Na}$, and $\mathrm{SO}_{4}$ (23-39\% increase), suggesting input of solutes from salt dissolution. This interpretation agrees with small shifts on the PCA biplot for samples from the two wells: data from 04MW show a slight trend along link $\varphi_{1}$, suggesting increased contributions from solute dissolution with time, whereas data for samples from $21 \mathrm{MW}$ trend toward the evaporation part of link $\varphi_{2}$ throughout the dry period. Only small changes $(<0.75)$ in SAR exist in samples from either well during the first year of the SDI operation. Water composition in samples from 24MW also changed considerably during the first approximately $1 \mathrm{yr}$ of SDI operation, showing a change to more dilute conditions (Figure 10). Post-SDI samples are generally depleted in $\mathrm{SO}_{4}, \mathrm{Mg}, \mathrm{K}, \mathrm{Ca}$, and $\mathrm{Cl}$ and enriched in $\mathrm{HCO}_{3}$ in $\mathrm{Na}$ relative to those collected in October 2008. Input of weakly titrated $\mathrm{Na}-$ $\mathrm{HCO}_{3}$-type injectate mixed directly into the groundwater might produce a similar chemical response (i.e., lower $\mathrm{Ca}, \mathrm{Mg}, \mathrm{K}, \mathrm{SO}_{4}$, and higher $\mathrm{HCO}_{3}$ ), but this is not consistent with soil water composition data within the SDI fields (Table 2; Figure 8). Data for samples from $24 \mathrm{MW}$ on the PCA biplot (Figure 7) show a modest trend with time toward the part of $\operatorname{link} \varphi_{2}$ associated with dilution, also suggesting mixing with a low TDS source. Because Na concentrations in 24MW were relatively constant ( $\sim 1 \%$ change) while $\mathrm{Ca}$ and $\mathrm{Mg}$ concentrations decreased, SAR increased from 7.7 to 8.4, despite a general decrease in TDS. These results seem paradoxical, given the highly concentrated $\mathrm{Na}-\mathrm{SO}_{4}$ type soil water collected just $1 \mathrm{~m}(3.3 \mathrm{ft})$ above the water table adjacent to this same well (Figure 8), suggesting that (1) the extent of elevated TDS soil waters is small and is rapidly diluted in the groundwater, (2) minimal transport of soil water to the saturated zone has occurred at this site, and/or (3) that a high degree of
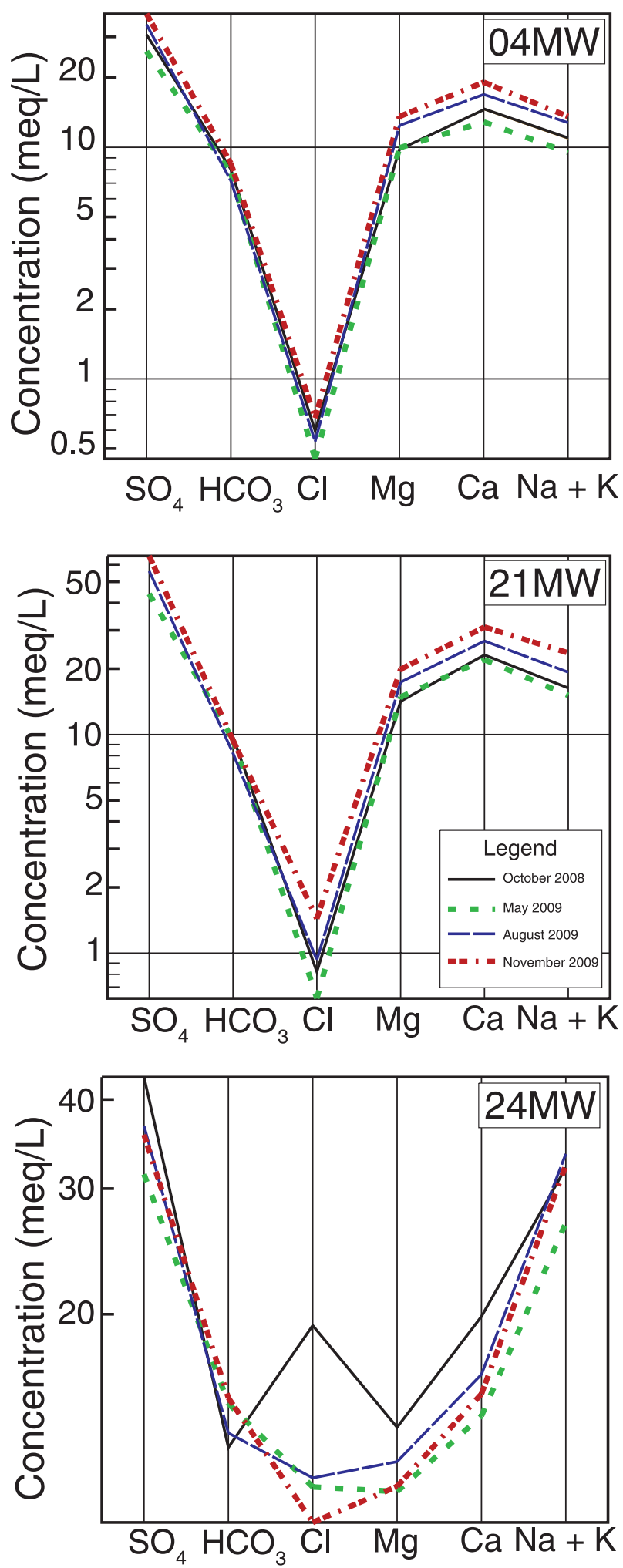

Figure 10. Schoeller diagram showing the major ion composition of groundwater samples from monitoring well $04 \mathrm{MW}$, $21 \mathrm{MW}$, and $24 \mathrm{MW}$ during the course of the study. Note the difference in y scale between plots. 
mineral precipitation and buffering occurs in the capillary zone. However, no obvious detrimental changes to groundwater chemistry were linked to initiation or operation of the SDI system at the Headgate Draw site during the first approximately 1 yr of SDI operation.

\section{SUMMARY AND CONCLUSIONS}

During the first year of SDI operation in the Headgate Draw site, significant changes to water balance, subsurface flow dynamics, and soil water chemistry were observed. Much of the added injectate entered the vadose system, altering soil water flow dynamics. Soils in SDI areas are near saturation below the emitters, and gravitationally driven downward water movement has developed in the lower parts of the vadose zone. Above the SDI emitters, the direction and rate of transport appear to depend on meteoric infiltration events, evapotranspiration rates, and possibly frozen soil during the winter. In non-SDI areas, by comparison, large-scale (>1 m [3.3 ft]) upward or downward water movement within the vadose zone appears minimal. Some of the injected water has been transported into the shallow aquifer system below the SDI fields, leading to the development of a small $(\sim 0.16 \mathrm{~m}[\sim 0.52 \mathrm{ft}]$ on average) groundwater mound. The anticipated increased CBM water application volumes in the future will likely magnify these changes.

Compositionally, the injectate is more dilute with respect to most constituents than the site groundwater. However, soil water collected from the site indicates that within the vadose zone, significant mixing and geochemical reactions are occurring. High TDS concentrations in soil water (as much as 44,300 mg/L) and zones of relative high electrical conductance, as measured by geophysical methods, suggest that evaporation and dissolution of native salts in the vadose zone appear to be primary controls on the composition of the injectate as it moves into soil column and mixes with native soil water. Initial evidence indicates that these processes vary with season. However, changes in groundwater chemistry at the site have been relatively minimal in response to the SDI operation, with a significant TDS increase in only one SDI well. This suggests that either vertical water transport exceeds solute transport or that a significant amount of geochemical buffering and mineral precipitation occurs in the capillary fringe. The composition of site soil water and groundwater continues to be monitored with time to evaluate trends. In addition, water quality and quantity along reaches of the Powder River and Crazy Women Creek immediately upstream and adjacent to the site will continue to be monitored to detect changes to surface water composition.

Results presented here are based on only approximately 1 yr of SDI operation at the Headgate Draw site. Seasonal variations in precipitation and climate corresponded to marked changes in water composition and flow at the site. Responses to year-to-year variability in meteorology and hydrologic conditions, however, may be much more difficult to predict with such limited data. In addition, impacts of longer term trends, including climate change, will require additional investigation; these efforts will only lead to better resource management.

Concerted modeling and vadose zone characterization efforts of SDI systems are currently underway. Several ground and airborne geophysical surveys are being conducted to characterize a larger part of the site and examine transient EM signals that may be attributed to SDI operations at the Headgate Draw site. Additional research is directed toward characterization of older, more established SDI sites that use CBM-produced waters. This research will provide feedback to operators and the public with regard to the operation of an SDI system and methods to minimize short-term and long-term effects of this technology relative to other disposal and/ or beneficial use options available to CBM producers.

\section{DISCLAIMER}

The use of trade and brand names is for descriptive purposes only and does not imply endorsement by the U.S. Government.

\section{REFERENCES CITED}

Aitchison, J., 1986, The statistical analysis of compositional data: London, United Kingdom, Chapman and Hall, 416 p.

Aitchison, J., and M. Greenacre, 2002, Biplots of compositional data: Journal of the Royal Statistical Society Series C (Applied Statistics), v. 51, p. 375-392, doi:10.1111/1467-9876.00275.

Ayars, J. E., R. A. Schoneman, F. Dale, B. Meso, and P. Shouse, 2001, Managing subsurface drip irrigation in the presence of shallow groundwater: Agricultural Water Management, v. 47, p. 243-264, doi:10.1016/S0378-3774(00)00106-2.

Bartos, T. T., and K. M. Ogle, 2002, Water quality and environmental isotopic analyses of groundwater samples collected from the Wasatch and Fort Union formations in areas of coalbed methane development: Implications to recharge and ground-water flow, eastern Powder River Basin, Wyoming: U.S. Geological Survey Water Resources Investigations Report 02-4045, 88 p. 
Bouwer, H., and R. C. Rice, 1976, A slug test for determining hydraulic conductivity of unconfined aquifers with completely or partially penetrating wells: Water Resources Research, v. 12, p. 423-428, doi:10.1029/WR012i003p00423.

Brinck, E. L., and C. D. Frost, 2007, Detecting infiltration and impacts of introduced water using strontium isotopes: Ground Water, v. 45, p. 554-568, doi:10.1111/j.1745-6584.2007.00345.x.

Brinck, E. L., and C. D. Frost, 2009, Evaluation of amendments used to prevent sodification of irrigated fields: Applied Geochemistry, v. 24, p. 2113-2122, doi:10.1016/j.apgeochem.2009.09.001.

Brinck, E. L., J. Drever, and C. D. Frost, 2008, The geochemical evolution of water coproduced with coalbed natural gas in the Powder River Basin, Wyoming: Environmental Geosciences, v. 15, p. 153-171, doi:10.1306/eg.01290807017.

Buccianti, A., and V. Pawlowsky-Glahn, 2005, New perspectives on water chemistry and compositional data analysis: Mathematical Geology, v. 37, p. 703-727, doi:10.1007/s1 1004-005-7376-6.

Clark, M. L., and J. P. Mason, 2006, Water-quality characteristics, including sodium adsorption ratios, for four sites in the Powder River Drainage Basin, Wyoming and Montana, water years 2001-2004: U.S. Geological Survey Scientific Investigations Report 2006-5113, 22 p.

Egozcue, J., V. Pawlowsky-Glahn, G. Mateu-Figueras, and C. BarcelóVidal, 2003, Isometric log-ratio transformations for compositional data analysis: Mathematical Geology, v. 35, p. 279-300, doi:10.1023/A:1023818214614.

Filzmoser, P., K. Hron, and C. Reimann, 2009a, Univariate statistical analysis of environmental (compositional) data: Problems and possibilities: Science of the Total Environment, v. 407, p. 61006108, doi:10.1016/j.scitotenv.2009.08.008.

Filzmoser, P., K. Hron, and C. Reimann, 2009b, Principal component analysis for compositional data with outliers: Environmetrics, v. 20, p. 621-632, doi:10.1002/env.966.

Filzmoser, P., K. Hron, and C. Reimann, 2010, The bivariate statistical analysis of environmental (compositional) data: Science of the Total Environment, v. 408, p. 4230-4238, doi:10.1016/j .scitotenv.2010.05.011.

Ganjegunte, G. K., G. F. Vance, and L. A. King, 2005, Soil chemical changes resulting from irrigation with water coproduced with coalbed natural gas: Journal of Environment Quality, v. 34, p. 2217-2227, doi:10.2134/jeq2005.0019.

Ganjegunte, G. K., L. A. King, and G. F. Vance, 2008, Cumulative soil chemistry changes from application of saline-sodic waters: Journal of Environmental Quality, v. 37, p. 128-138.

Geboy, N. J., M. A. Engle, K. T. Schroeder, and J. W. Zupancic, 2011, Summary of inorganic compositional data for groundwater, soil water, and surface water samples at the Headgate Draw subsurface drip irrigation site, Johnson County, Wyoming, Version 1: U.S. Geological Survey Digital Data Series, 11 p.

Gee, G. W., and D. Or, 2002, Particle size analysis, in J. H. Dane and G. C. Topp, eds., Methods of soil analysis: Part 4. Physical methods, Soil Science Society of America Book Series 5: Madison, Wisconsin, Soil Science Society of America, p. 255-293.

Gupta, R. K., D. K. Bhumbla, and I. P. Abrol, 1984, Effect of sodicity, $\mathrm{pH}$, organic matter, and calcium carbonate on the dispersion behavior of soils: Soil Science, v. 137, p. 245-251, doi:10.1097/00010694-198404000-00006.

Healy, R. W., C. A. Rice, T. T. Bartos, and M. P. McKinley, 2008, Infiltration from an impoundment for coal-bed natural gas, Powder River Basin, Wyoming: Evolution of water and sediment chemistry: Water Resources Research, v. 44, p. W06424, doi:10.1029/2007WR006396.

Jackson, R. E., and K. J. Reddy, 2007, Geochemistry of coalbed natural gas (CBNG)-produced water in Powder River Basin, Wyoming: Salinity and sodicity: Water, Air, and Soil Pollution, v. 184, p. 49-61, doi:10.1007/s11270-007-9398-9.
Leopold, L. B., and J. P. Miller, 1954, A postglacial chronology for some alluvial valleys in Wyoming: U.S. Geological Survey Water-Supply Paper 1261, 89 p.

Lipinski, B. A., J. I. Sams, B. D. Smith, and W. Harber, 2008, Using HEM surveys to evaluate disposal of by-product water from CBNG development in the Powder River Basin, Wyoming: Geophysics, v. 73, p. B77-B84, doi:10.1190/1.2901200.

Otero, N., R. Tolosana-Delgado, A. Soler, V. Pawlowsky-Glahn, and A. Canals, 2005, Relative versus absolute statistical analysis of compositions: A comparative study of surface waters of a Mediterranean river: Water Research, v. 39, p. 1404-1414, doi:10 $.1016 /$ j.watres.2005.01.012.

Parkhurst, D. L., and C. A. J. Appelo, 1999, User's guide to PHREEQC (version 2): A computer program for speciation, batch-reaction, one-dimensional transport, and inverse geochemical calculations: U.S. Geological Survey Water Resources Investigations Report 99-4259, 312 p.

R Development Core Team, 2010, R: A language and environment for statistical computing, reference index version 2.11.1: http ://www.R-project.org.

Rice, C. A., and V. F. Nuccio, 2000, Water produced with coalbed methane: U.S. Geological Survey Fact Sheet FS-156-00, 2 p.

Rice, C. A., T. T. Bartos, and M. S. Ellis, 2002, Chemical and isotopic composition of water in the Fort Union and Wasatch formations of the Powder River Basin, Wyoming and Montana: Implications for coalbed methane development, in S. D. Schwochow and V. F. Nuccio, eds., Coalbed methane of North America: II. Rocky Mountain Association of Geologists, p. 53-70.

Sams, J. I., B. D. Smith, G. Veloski, B. J. Minsley, M. A. Engle, R. Hammack, and J. Zupancic, 2010, Third year of subsurface drip irrigation monitoring using GEM2 electromagnetic surveys, Powder River Basin, Wyoming (abs.): Abstracts from the 2010 Symposium on the Application of Geophysics to Engineering and Environmental Problems, 9 p.

Templ, M., P. Filzmoser, and C. Reimann, 2008, Cluster analysis applied to regional geochemical data: Problems and possibilities: Applied Geochemistry, v. 23, p. 2198-2213, doi:10.1016/j .apgeochem.2008.03.004.

Templ, M., K. Hron, and P. Filzmoser, 2010, robCompositions: Robust estimation for compositional data, $\mathrm{R}$ package version 1.4.3.

Tolosana-Delgado, R., N. Otero, V. Pawlowsky-Glahn, and A. Soler, 2005, Latent compositional factors in the Llobregat River Basin (Spain) hydrogeochemistry: Mathematical Geology, v. 37, p. 681-702, doi:10.1007/s1 1004-005-7375-7.

U.S. Bureau of Land Management, 2003, Final environmental impact statement and proposed plan amendment for the Powder River Basin oil and gas project: U.S. Bureau of Land Management Report WY-070-02-065.

U.S. Energy Information Administration, 2009, U.S. coalbed methane production: http://tonto.eia.doe.gov/dnav/ng/ng_enr_cbm _a_EPG0_r52_Bcf_a.htm (accessed January 31, 2010).

U.S. Geological Survey, 2006, Collection of water samples: National Field Manual for the Collection of Water-Quality Data, Book 9, Handbooks for Water-Resources Investigations, $166 \mathrm{p}$.

U.S. Geological Survey, 2010, National Water Information System: Daily discharge data for Powder River (site 06317000) and Crazy Woman Creek (site 06316400): http://waterdata.usgs .gov/nwis/ (accessed February 7, 2010).

Western Regional Climate Center, 2010, Monthly climate summary for the Clearmont Southwest Station, Wyoming: http://www .wrcc.dri.edu/cgi-bin/cliMAIN.pl?wyl816 (accessed January 31, 2010).

Wyoming Oil and Gas Conservation Commission, 2010, Coalbed methane production by month for the Powder River Basin: http://wogcc.state.wy.us/coalbedchart.cfm (accessed June 11, 2010). 